Jacek Chądzyński *

\author{
ROZDZIA $ヒ$ V
}

\title{
Udział podmiotów trzeciego sektora w rozwoju kapitału ludzkiego w regionie łódzkim
}

\section{Wstęp - pojęcie, funkcje i cele trzeciego sektora}

Przez długie lata, w kontekście gospodarki i zasad jej funkcjonowania, wyodrębniano dwa przeciwstawne sobie sektory - prywatny i publiczny. Pierwszy, składający się z nastawionych na zysk podmiotów stanowiących własność prywatną, tworzących podstawy materialne funkcjonowania społeczeństwa i funkcjonujących $\mathrm{w}$ oparciu o prawa rynkowe oraz drugi, składający się z kolei $\mathrm{z}$ instytucji państwowych i samorządowych dbających o właściwe funkcjonowanie państwa i realizację stawianych przed nim zadań. Główny cel istnienia podmiotów należących do tego sektora, to przede wszystkim zaspokajanie potrzeb społecznych. Stopniowo jednak zaczęły się pojawiać i zyskiwać na znaczeniu podmioty, które trudno było zaklasyfikować do któregokolwiek z tych dwóch sektorów, które „występują między oraz na styku sektora prywatnego i publicznego"1. Od połowy minionego wieku zaczął więc być wyodrębniany trzeci sektor $^{23}$, skupiający podmioty nie stanowiące elementu struktury państwa, działające nie dla zysku, a na rzecz zaspokojenia potrzeb poszczególnych osób, grup,

\footnotetext{
* Adiunkt, Katedra Gospodarki Samorządu Terytorialnego, Wydział Ekonomiczno-Socjologiczny, Uniwersytet Łódzki. Email: jacekch@uni.lodz.pl

${ }^{1}$ K. Kietlińska, Rola trzeciego sektora w społeczeństwie obywatelskim, Wydawnictwo Difin, Warszawa 2010, s. 50.

${ }^{2}$ Chociaż genezy jego powstania można się doszukiwać już w starożytności, a na pewno w średniowieczu, kiedy Kościół Katolicki zaczął tworzyć i rozwijać w sposób zinstytucjonalizowany działalność dobroczynną wobec najbardziej potrzebujących chorych, biednych i bezdomnych. Zob. E. Leś, Działalność dobroczynna w Europie i Ameryce. Tradycje i współczesność, BORDO, Warszawa 1999 oraz E. Leś, Od filantropii do pomocniczości. Studium porównawcze rozwoju i działalności organizacji społecznych, Dom Wydawniczy ELIPSA, Warszawa 2000.

${ }^{3}$ Pojęcie trzeci sektor jest używane zamiennie $\mathrm{z}$ wieloma innymi określeniami, np.: sektor organizacji pozarządowych, sektor obywatelski, sektor społeczny, sektor non-profit, voluntary sector, czy independent sector. Każde z nich eksponuje jednak inną cechę pozwalającą odróżnić ten sektor od dwóch pozostałych.
} 
czy całego społeczeństwa oraz tworzące i umacniające w społeczeństwie poczucia wspólnoty. Trzeci sektor funkcjonuje, bo oprócz zapału i pracy tworzących go ludzi otrzymuje pomoc ze strony sektora pierwszego, w postaci środków na finansowanie działających $\mathrm{w}$ jego ramach organizacji oraz drugiego sektora, który oprócz pomocy finansowej zapewnia także prawne i organizacyjne możliwości działania ${ }^{4}$.

Podmioty tworzące ten sektor nazywane są najczęściej organizacjami trzeciego sektora (third sector organizations), albo organizacjami pozarządowymi (non-governmental organizations $)^{5}$, chociaż nie brakuje oczywiście innych określeń, takich jak: organizacje non-profit (non for profit), organizacje niezależne (independent organizations), organizacje społeczne, organizacje charytatywne lub dobroczynne (charitable organizations), organizacje woluntarystyczne lub ochotnicze (voluntary organizations), organizacje obywatelskie, czy organizacje pożytku publicznego (zob. uwaga w przypisie 3). Podmioty te charakteryzują się:

- istnieniem struktury organizacyjnej oraz formalną rejestracją;

- strukturalną niezależnością od władz publicznych;

- niezarobkowym charakterem;

- suwerennością i samorządnością;

- dobrowolnością przynależności ${ }^{6}$.

Do najczęściej wskazywanych funkcji, które pełnią organizacje pozarządowe należą:

- pomocowa - związana z zaspokajaniem podstawowych potrzeb ludzkich, takich jak np. zaspokojenie głodu, czy potrzeba poczucia bezpieczeństwa;

- afiliacyjna - dotycząca realizacji potrzeby przynależności jednostki ludzkiej do jakiejś grupy społecznej;

- ekspresyjna - związana z zaspokajaniem potrzeby samorealizacji człowieka;

- opiekuńczo-wychowawcza - dotycząca kształtowania osobowości człowieka w całym okresie jego życia;

- integracyjna - związana z udziałem w procesach budowania więzi społecznych, rozwojem umiejętności nawiązywania kontaktów i porozumień wewnątrz określonej grupy społecznej, ale i na zewnątrz, pomiędzy grupami ${ }^{7}$.

${ }^{4}$ J. Wygnański, Terminologia [w:] A. Gałązka (red.), Elementarz III sektora, Stowarzyszenie Klon/Jawor, Warszawa 2005, s. 11-14.

${ }^{5} \mathrm{~W}$ dalszej części tekstu te dwie nazwy będą używane zamiennie.

${ }^{6}$ Definicja stworzona na potrzeby międzynarodowego badania John Hopkins University (Baltimore, USA) - za: A. Gałązka (red.), Elementarz III sektora, Stowarzyszenie Klon/Jawor, Warszawa 2005, s. 13.

${ }^{7}$ M. Załuska, Prawne i organizacyjne ramy działania organizacji pozarzadowych [w:] M. Załuska, J. Boczoń (red.), Organizacje pozarzqdowe w społeczeństwie obywatelskim, Wydawnictwo Śląsk, Katowice 1998, s. 38-40. 
Ilość podmiotów tworzących ten sektor decyduje o ich różnorodności. Jedna z typologii organizacji pozarządowych wyodrębnia ze względu na profil działalności:

- organizacje samopomocowe - działające na rzecz swoich członków;

- organizacje opiekuńcze - świadczące usługi dla wszystkich lub tylko wybranych grup społecznych, które tego potrzebuja;

- organizacje przedstawicielskie - reprezentujące interesy jakichś społeczności, grup społecznych, zawodowych;

- organizacje mniejszości - reprezentujące interesy grup mniejszościowych;

- organizacje tworzone ad hoc - powstające „spontanicznie”, jako reakcja na pojawiający się problem;

- organizacje hobbystyczno-rekreacyjne - grupujące osoby mające tę samą (podobna) sferą zainteresowań;

- organizacje zadaniowe - wykonujące pewne funkcje zlecone przez władze publiczne;

- $\quad$ organizacje „tradycyjne” - o szerokiej formule działalności ${ }^{8}$.

Bardzo różnorodne jest również spektrum obszarów działalności tych organizacji, które obejmuje praktycznie wszystkie dziedziny, związane zarówno z życiem pojedynczych osób, grup społecznych, zorganizowanych podmiotów (w tym prowadzących działalność gospodarczą), jak i funkcjonowaniem całych terytoriów.

Jak to już zostało wcześniej zasygnalizowane, nie tylko ilość, ale i rola organizacji tworzących trzeci sektor stale wzrasta (przynajmniej, jeśli chodzi o państwa o ustroju demokratycznym). Zgodnie z wciąż aktualnymi koncepcjami new public management, czy local governance $e^{9}$ są one ważnym partnerem władz lokalnych i regionalnych w kreowaniu i realizacji procesów rozwoju terytorialnego. Jednym z niezwykle istotnych czynników rozwoju jest bez wątpienia poziom, czy może trafniej, jakość kapitału ludzkiego dostępnego w ramach określonego terytorium ${ }^{10}$. Wśród funkcjonujących organizacji pozarządowych nie brakuje

${ }^{8}$ Z. Lasocik, Kilka uwag o roli organizacji pozarzqdowych $w$ państwie demokratycznym, Fundusz Współpracy, Warszawa 1994, s. 5.

${ }^{9}$ Szerzej na temat tych koncepcji np. w : A. Zalewski, Reformy sektora publicznego $w$ duchu nowego zarzadzania publicznego [w:] Nowe zarzadzanie publiczne $w$ polskim samorzadzie terytorialnym, A. Zalewski (red.), SGH, Warszawa 2007, s. 11-75; P. John, Governance In Western Europe, SAGE Publications Ltd., London - Thousand Oaks - New Delhi 2004, s. 6-22; A. Jewtuchowicz, Terytorium i wspótczesne dylematy jego rozwoju, Wydawnictwo Uniwersytetu Łódzkiego, Łódź 2005, s. 125-129.

${ }^{10}$ Kapitał ludzki można rozpatrywać zarówno w wąskim, jak i szerokim ujęciu. W tym pierwszym przypadku utożsamiany jest $\mathrm{z}$ wiedza, poziomem wykształcenia $\mathrm{i}$ indywidualnymi kompetencjami człowieka, dotyczącymi realizacji założonych zadań oraz celów społecznych. Natomiast w drugim, jako wszystkie cechy psychofizyczne danej jednostki, do których zalicza się: wrodzone zdolności, wykształcenie, zasób posiadanej wiedzy, indywidualne umiejętności, 
takich, których działalność przyczynia się w mniejszym lub większym stopniu do jego poprawy ${ }^{11}$.

\section{Trzeci sektor w Polsce}

Początek tworzenia się organizacji dobroczynnych w Polsce jest ściśle związany z chrystianizacją naszego kraju i rozwojem instytucji Kościoła Katolickiego, natomiast pierwsze świeckie organizacje samopomocowe (górnicze kasy zapomogowe) zaczęły powstawać na przełomie XV i XVI w. Poważniejszą rolę organizacje społeczne, w postaci stowarzyszeń naukowych i edukacyjnych, czy kółek rolniczych, zaczęły jednak odgrywać dopiero w XIX w., a więc w okresie rozbiorów. Rozwój organizacji pozarządowych, który nastąpił wraz z uzyskaniem przez Polskę w 1918 r. niepodległości został przerwany brutalnie przez II wojnę światową. Jej zakończenie nie oznaczało jednak ,powrotu do normalności”. Władze komunistyczne bardzo szybko ograniczyły możliwości swobody zrzeszania się i tworzenia niezależnych od państwa organizacji, realizujących niezaspokajane przez nie potrzeby społeczne. Dopiero zmiana systemu polityczno-gospodarczego w 1989 r. przyniosła możliwość rozwoju społeczeństwa obywatelskiego i będących jego przejawem organizacji pozarządowych.

Przyjęta dopiero po kilkunastu latach od przełomu ustrojowego ustawa z dnia 24 kwietnia 2003 r. o działalności pożytku publicznego i o wolontariacie ${ }^{12}$ przyniosła wreszcie powszechnie obowiązująca, prawną definicję organizacji pozarządowych, którymi zgodnie z art. 3 ust. 2 tej ustawy są: niebędące jednostkami sektora finansów publicznych, w rozumieniu przepisów ustawy o finansach publicznych, i niedziałające w celu osiagnięcia zysku, osoby prawne lub jednostki nieposiadające osobowości prawnej, utworzone na podstawie przepisów ustaw, w tym fundacje i stowarzyszenia. Oprócz tego dokumentu, do najważniejszych aktów prawnych normujących możliwość istnienia i regulujących zasady funkcjonowania organizacji pozarządowych należą: Konstytucja Rzeczypospolitej Polskiej z dnia 2 kwietnia 1997 roku $^{13}$, ustawa z dnia 6 kwietnia 1984

doświadczenie zawodowe, a także stan zdrowia, prezentowaną aktywność społeczną i ekonomiczna, światopogląd oraz poziom kulturalny. Szerzej w: N. Bontis, National intellectual capital index; the benchmarking of Arab Countries, Journal of Intellectual Capital, 2002 oraz W. Florczak, Kapital ludzki a rozwój gospodarczy [w:] W. Welfe (red.), Gospodarka oparta na wiedzy, Polskie Wydawnictwo Ekonomiczne, Warszawa 2007.

${ }^{11}$ Pełne zestawienie obszarów działalności organizacji pozarządowych przyczyniających się do poprawy jakości kapitału ludzkiego, przyjęte na potrzeby opisywanych w dalszej części tekstu badań, zostało przedstawione w formie wypunktowania na s. 9-10.

${ }^{12}$ Dz. U. $2003 \mathrm{Nr} 96$, poz. 873 z późn. zm.

${ }^{13}$ Dz. U. $1997 \mathrm{Nr} 78$, poz. 483 z późn. zm. 
roku o fundacjach ${ }^{14}$ oraz ustawa $\mathrm{z}$ dnia 7 kwietnia 1989 roku Prawo o stowarzyszeniach $^{15}$. Konstytucja RP w art. 12 zapewnia wolność tworzenia i działania związków zawodowych, organizacji społeczno-zawodowych rolników, stowarzyszeń, ruchów obywatelskich, innych dobrowolnych zrzeszeń oraz fundacji, a w art. 58 gwarantuje wolność zrzeszania się i możliwość swobodnego zakładania organizacji o charakterze dobrowolnym oraz działania w niej. Pozostałe $\mathrm{z}$ wymienionych ustaw reguluja $\mathrm{z}$ kolei zasady tworzenia i funkcjonowania dwóch podstawowych form prawnych, w jakich prowadzona jest działalność trzeciego sektora w Polsce, a więc fundacji i stowarzyszeń.

Trudno jest wskazać dokładną liczbę organizacji pozarządowych, faktycznie funkcjonujących obecnie na terenie naszego kraju. Prowadzone oficjalnie statystyki pozostawiaja pod tym względem wiele do życzenia. Opublikowany w tym roku raport z badań zrealizowanych przez Stowarzyszenie Klon/Jawor koncentruje się tradycyjnie na organizacjach pozarządowych, wchodzących w skład trzeciego sektora w ramach jego „wąskiej” definicji ${ }^{16}$ i podaje liczbę ok. 83 tys. fundacji i stowarzyszeń (przy czym ok. 11 tys. z nich to fundacje, a ok. 72 tys. stowarzyszenia). Zdaniem Autorów raportu fundacje i stowarzyszenia stanowią z kolei ok. 80\% ogólnej liczby podmiotów uwzględnianych w „szerokiej” definicji organizacji pozarządowych (w sumie ok. 111 tys. podmiotów). Przyjmują jednak jednocześnie, że tylko ok. $75 \% \mathrm{z}$ nich faktycznie funkcjonuje, a nie jest tylko „martwymi duszami”"

Jak to już zostało wcześniej napisane, część z tych organizacji poprzez swoją działalność przyczynia się, a przynajmniej powinna, do poprawy jakości kapitału ludzkiego w ramach jednostek terytorialnych, na terenie których funkcjonują. Na potrzeby badań opisywanych w dalszej części tekstu, podjęto próbę wyodrębnienia ich w województwie łódzkim.

\section{Założenia badawcze}

Głównym celem badań była $\mathrm{z}$ jednej strony próba zidentyfikowania w województwie łódzkim jednostek samorządu terytorialnego wykorzystujących

\footnotetext{
${ }^{14}$ Tekst jedn. Dz. U. $1991 \mathrm{Nr}$ 46, poz. 203 z późn. zm.

${ }^{15}$ Tekst jedn. Dz. U. 2001 Nr 79, poz. 855 z późn. zm.

${ }^{16} \mathrm{~W}$ rodzimej literaturze przedmiotu wyodrębnia się najczęściej „wąską” i ,szeroką” definicję trzeciego sektora. Zgodnie z pierwszą z nich, do organizacji wchodzących w skład tego sektora zalicza się właśnie wyłącznie fundacje i stowarzyszenia, a w „szerokiej” uwzględnia się również m.in. związki i samorządy zawodowe, związki pracodawców, kółka rolnicze, czy koła gospodyń wiejskich. Zob. np. J. Wygnański, Terminologia [w:] A. Gałązka (red.), Elementarz III sektora, Stowarzyszenie Klon/Jawor, Warszawa 2005, s. 11-14.

${ }^{17}$ J. Przewłocka, P. Adamiak, J. Herbst, Podstawowe fakty o organizacjach pozarzadowychraport z badania 2012, Stowarzyszenie Klon/Jawor, Warszawa 2013, s. 23-25.
} 
partnerstwo publiczno-społeczne w działaniach zmierzających do podnoszenia jakości kapitału ludzkiego, a z drugiej - organizacji pozarządowych zaangażowanych w tego typu działania.

W związku z tak sformułowanym celem, zostały postawione następujące pytania badawcze:

1) Czy i w jakim zakresie dochodzi do współpracy na poziomie samorząd lokalny - organizacje pozarządowe?

2) Czy i w jakich obszarach oraz w jakiej formie samorządy lokalne współpracują z organizacjami pozarządowymi w zakresie rozwoju kapitał ludzkiego?

3) Jak samorządy lokalne oceniają działalność organizacji pozarządowych w zakresie rozwoju kapitału ludzkiego?

4) Jakie korzyści ze współpracy wynikają zarówno dla organizacji pozarządowych, jak i samorządów, ale przede wszystkim członków lokalnych społeczności?

5) Jakie są główne bariery współpracy samorządów lokalnych z organizacjami pozarządowymi zaangażowanymi w podnoszenie jakości kapitału ludzkiego na poziomie lokalnym?

Przyjęte $\mathrm{w}$ trakcie przygotowywania badań podstawowe tezy badawcze brzmią następująco:

1. Samorządy lokalne nie wykorzystują w pełni potencjału, jakim dysponują organizacje pozarządowe działające w obszarze rozwoju kapitału ludzkiego.

2. Organizacje pozarządowe działające $w$ tym obszarze nie zawsze potrafią wykorzystywać istniejące możliwości podejmowania współpracy z władzami lokalnymi.

3. Samorządy lokalne zbyt często podejmują współpracę z organizacjami pozarządowymi, która ogranicza się jedynie do /do-/finansowania zadań publicznych realizowanych przez organizacje pozarządowe.

W celu odpowiedzi na postawione powyżej pytania oraz zweryfikowania postawionych tez badawczych, podjęto decyzję o realizacji badań ankietowych skierowanych zarówno do przedstawicieli samorządów lokalnych, jak i organizacji pozarządowych prowadzących na terenie województwa łódzkiego swoją działalność w zakresie rozwoju kapitału ludzkiego ${ }^{18}$.

18 Autorami opisywanego w dalszej części artykułu badania są dr J. Chądzyński oraz dr Z. Przygodzki. Badanie zostało zrealizowane w ramach projektu badawczego pt. Polityka i narzędzia kreowania kapitału ludzkiego w regionie, sfinansowanego ze środków na naukę w latach 2010-2013, nr N N114 183938. 


\section{Współpraca gmin i powiatów regionu łódzkiego z organizacjami trzeciego sektora wspierającymi rozwój kapitału ludzkiego}

W pierwszej kolejności zostały poddane badaniu wszystkie powiaty i gminy z terenu województwa łódzkiego - odpowiednio 24 powiaty i 177 gmin, w tym 18 gmin miejskich, 25 miejsko-wiejskich i 134 wiejskie - w sumie 201 jednostek samorządu terytorialnego (jst) ${ }^{19}$. Kwestionariusze odesłało $180 \mathrm{z}$ nich $(22$ powiaty, 18 gmin miejskich, 18 gmin miejsko-wiejskich oraz 122 gminy wiejskie), co dało zwrotność na poziomie $89,6 \%{ }^{20}$.

Przez pierwszych kilkanaście lat po przełomie ustrojowym brakowało w polskim ustawodawstwie uregulowań prawnych, dotyczących zasad wspó1pracy jednostek samorządu terytorialnego z podmiotami tworzącymi tzw. trzeci sektor. Dopiero wraz z wejściem w życie wspomnianej już ustawy z dnia 24 kwietnia 2003 r. o działalności pożytku publicznego i o wolontariacie zostały w końcu unormowane zasady współpracy tego typu podmiotów z administracją publiczną, w tym oczywiście samorządową. Nakłada ona na jednostki samorzą$\mathrm{du}$ terytorialnego obowiązek uchwalenia rocznego (ewentualnie wieloletniego) programu współpracy $\mathrm{z}$ organizacjami pozarządowymi oraz podmiotami wymienionymi w art. 3 ust. 3 ww. ustawy ${ }^{21}$.

Zdecydowana większość badanych jst posiada jednoroczne programy współpracy - $155(86,1 \%)$, a program wieloletni jedynie 18 jst (10\%). Co dziwne i niepokojące, 7 badanych jst (3,9\%) odpowiedziało, że nie posiada w ogóle tego typu obowiązującego dokumentu. Wśród jednostek, które posiadają program wieloletni, najczęstszym rozwiązaniem jest 5-letni okres jego obowiązywania (w połowie przypadków), a w następnej kolejności okres 3-letni (rozwiązanie takie zostało przyjęte $\mathrm{w}$ co czwartej jednostce). Na posiadanie dokumentu

${ }^{19}$ Dane na podstawie bazy jednostek samorządu terytorialnego dostępnej pod adresem internetowym: http://www.administracja.mac.gov.pl.

${ }^{20}$ Dla powiatu poziom zwrotności wyniósł $91,7 \%$, dla gmin miejskich $100 \%$, dla wiejskich $98,4 \%$, a zdecydowanie najmniejszy dla miejsko-wiejskich $-72 \%$.

${ }^{21}$ Są to:

1) osoby prawne i jednostki organizacyjne działające na podstawie przepisów o stosunku Państwa do Kościoła Katolickiego w Rzeczypospolitej Polskiej, a także do innych kościołów i związków wyznaniowych oraz o gwarancjach wolności sumienia i wyznania, jeżeli ich cele statutowe obejmują prowadzenie działalności pożytku publicznego;

2) stowarzyszenia jednostek samorządu terytorialnego;

3) spółdzielnie socjalne;

4) spółki akcyjne i spółki z ograniczoną odpowiedzialnością oraz kluby sportowe będące spółkami działającymi na podstawie przepisów ustawy z dnia 25 czerwca 2010 r. o sporcie (Dz. U. 2010, $\mathrm{Nr} 127$, poz. 857 , z późn. zm.), które nie działają w celu osiagnnięcia zysku oraz przeznaczają całość dochodu na realizację celów statutowych oraz nie przeznaczają zysku do podziału między swoich udziałowców, akcjonariuszy i pracowników. 
wieloletniego proporcjonalnie ponad 2 razy częściej zdecydowały się gminy miejsko-wiejskie oraz powiaty (odpowiednio $20 \%$ i $18 \%$ ), niż gminy miejskie i wiejskie (odpowiednio 7\% i 8\%).

W 160 przypadkach $(88,9 \%)$, badane jednostki zapraszały do uczestnictwa w pracach nad opracowaniem programu współpracy funkcjonujące na ich terenie organizacje pozarządowe (chociażby w postaci ich reprezentantów), w pozostałych przypadkach proces opracowywania programu odbywał się niestety bez udziału samych zainteresowanych.

W ramach tego uczestnictwa, samorządy lokalne zdecydowanie najczęściej decydują się na przedstawienie organizacjom pozarządowym gotowych projektów programów współpracy, w celu ich zaopiniowania. Taka sytuacja ma miejsce w przypadku 76,9\% badanych gmin i powiatów. Nie jest to sytuacja zła, o ile jest konsekwencją zaangażowania organizacji na wcześniejszych etapach przygotowywania programu współpracy. W praktyce jednak nie zawsze jest tak dobrze. Do konsultowania założeń, dotyczących potrzeb finansowych organizacji pozarządowych, działających na terenie gminy lub powiatu, dochodzi w 57,5\% przypadków, czego konsekwencją jest później możliwość lepszego ich zaspokojenia. Niewiele rzadziej organizacje proszone są przez opracowujących program o wskazanie potrzeb pozafinansowych organizacji (lokalowych, szkoleniowych itp.) - w 50\% udzielonych odpowiedzi. Niestety tylko w niecałych $30 \%$ badanych gmin i powiatów organizacje przekazują w ramach konsultacji własne propozycje dotyczące zadań priorytetowych, realizują, bądź tylko współpracują przy opracowywaniu badań, mających na celu ustalenie potrzeb mieszkańców, które mogłyby być zaspokajane przez organizacje pozarządowe. To niepokojące, gdyż organizacje pozarządowe są właśnie często wyrazicielami potrzeb mieszkańców i często powstają w wyniku niezaspokajania ich przez działające na danym obszarze podmioty publiczne.

Jeśli chodzi o wszystkie wskazane powyżej formy konsultacji, to gminy wypadają lepiej od powiatów, przy czym gminy miejskie i wiejskie częściej pytają o potrzeby finansowe organizacji pozarządowych, a z kolei gminy miejskowiejskie w większym stopniu koncentrują się na konsultacjach dotyczących potrzeb pozafinansowych, np. lokalowych, czy związanych z doposażeniem sprzętowym. W przypadku opiniowania natomiast, niewielką przewagę uzyskują powiaty.

To, że organizacje coś proponują, przedstawiają własne sugestie, czy gotowe rozwiązania, nie oznacza wcale, że są one w efekcie końcowym uwzględnione w gotowym programie. W $21,9 \%$ przypadków badane jednostki deklarowały, że uwagi organizacji pozarządowych zawsze znajdują odzwierciedlenie w ostatecznych zapisach programu. Cieszyć może wysoki odsetek $(44,4 \%)$ odpowiedzi, które wskazują na częste ( $\mathrm{w}$ minimum połowie przypadków) uwzględnianie uwag organizacji. W 15,6\% badanych jednostek samorządowych, sformułowane 
przez organizacje pozarządowe uwagi są uwzględniane rzadko (w mniej niż w połowie przypadków), a w 6,3\% nigdy nie zostały uwzględnione. Zwłaszcza ta ostatnia wielkość może zasmucić wszystkich propagatorów zwiększania obszarów i częstotliwości współpracy władz lokalnych z podmiotami trzeciego sektora. Trzeba przecież pamiętać, że organizacje pozarządowe są swoistym uosobieniem aktywności obywatelskiej. Taka sytuacja niepokoi zwłaszcza w obliczu mocno propagowanej idei partycypacji lokalnej społeczności, w decyzjach podejmowanych przez lokalne władze. W przypadku pozostałych 19 $(11,9 \%)$, spośród 160 gmin i powiatów, zdaniem badanych, organizacje pozarządowe nie miały żadnych uwag, które mogłyby zostać uwzględnione w przygotowywanym programie współpracy.

$\mathrm{Na}$ brak uwag wskazywały najczęściej osoby reprezentujące gminy wiejskie (14,3\% spośród gmin tego typu). Z kolei w gminach miejsko-wiejskich, proporcjonalnie do ich ilości, najczęściej uwagi przedstawicieli organizacji pozarządowych nie były w ogóle, lub rzadko brane pod uwagę (44,5\% gmin tego typu). Natomiast $\mathrm{w}$ gminach miejskich stosunkowo najrzadziej (w 3,8\% przypadków) mamy do czynienia z sytuacją uwzględniania zawsze i wszystkich uwag formułowanych przez osoby reprezentujące trzeci sektor. Na tym tle najlepiej wypadają powiaty, w których odsetek jednostek często lub zawsze uwzględniających uwagi organizacji pozarządowych okazał się najwyższy i wyniósł łącznie $70 \%$.

Spośród powodów nieuwzględnienia uwag sformułowanych przez organizacje pozarządowe badani wskazywali przede wszystkim na brak środków finansowych potrzebnych do zaspokojenia sformułowanych przez nie oczekiwań (86 przypadków - 53,8\%). Zdecydowanie rzadziej wspominali o braku potrzeby uwzględniania uwag $(28,5 \%)$, oderwaniu oczekiwań organizacji od ich realnych potrzeb (17,1\%), czy potrzeb mieszkańców $(12,0 \%)$. W przypadku $16,3 \%$ badanych gmin, odpowiadający usprawiedliwiali brak uwzględniania uwag organizacji brakiem realnej potrzeby. Natomiast w $10,1 \%$ przypadków badani thumaczyli, że propozycje organizacji pozarządowych znalazły już wcześniej odzwierciedlenie $\mathrm{w}$ istniejących zapisach programu współpracy.

Lokalne władze dość rzadko decydują się na aktualizowanie istniejących już programów w trakcie ich realizacji (22 przypadki - 13,8\% spośród odpowiadających). Głównej przyczyny takiego stanu rzeczy można upatrywać w fakcie dominacji programów jednorocznych, w przypadku których długotrwałość procesu ewentualnej zmiany wykraczałby poza okres obowiązywania samego programu.

Wśród organizacji, z którymi współpracują gminy są oczywiście takie, których działalność z zasady powinna, a w praktyce może mieć wpływ na jakość kapitału ludzkiego w ramach danej jednostki, przyczyniając się do podnoszenia jego poziomu. Na potrzeby badań, do tego grona zaliczone zostały organizacje pozarządowe, których działalność koncentruje się na:

- prowadzeniu szkół lub edukacji pozaszkolnej;

- realizacji szkoleń i doradztwa zawodowego; 
- podnoszeniu poziomu innowacyjności podmiotów działających na terenie badanej jednostki terytorialnej;

- wspieraniu zainteresowań i działalności hobbystycznej wśród mieszkańców;

- propagowaniu kultury fizycznej i zdrowego trybu życia;

- propagowaniu i rozwoju kultury w danej jednostce terytorialnej;

- ochronie i promocji zdrowia;

- aktywizowaniu członków lokalnej społeczności i wspieraniu powstawania i rozwoju wspólnot zrzeszających mieszkańców we wspólnym celu;

- podnoszeniu poczucia porządku i bezpieczeństwa w gminie, czy powiecie.

Wszystkie z badanych jednostek zadeklarowały, że współpracują z przynajmniej jedną organizacją pozarządową której działalność można zaklasyfikować do któregoś z powyższych punktów. Największą popularnością cieszą się organizacje zajmujące się propagowaniem kultury fizycznej i zdrowego stylu życia (współpraca w 162 ze 174 badanych jst). W następnej kolejności do współpracy dochodzi z organizacjami zajmującymi się aktywizacją społeczności lokalnych i wspomaganiem rozwoju wspólnot (104 wskazania), ochroną i promocją zdrowia (81 przypadków) oraz działalnością edukacyjną (71 przypadków). Biorąc pod uwage wyniki badań zrealizowanych w roku 2012 przez Stowarzyszenie Klon/Jawor ${ }^{22}$, nie powinna dziwić stosunkowo duża liczba wskazań na organizacje działające w obszarach związanych z kulturą fizyczną, działalnością edukacyjna, czy ochroną i promocją zdrowia. Na pierwszy rzut oka zaskoczeniem może być natomiast niski odsetek organizacji związanych z kulturą i sztuką. Trzeba jednak w tym miejscu wziąć pod uwagę, że większość badanych jednostek, to gminy wiejskie, a więc podmioty małe, w których organizacje o takim profilu działalności często wcale nie występują. Potwierdzeniem tej opinii może być fakt, że najwyższy odsetek wskazań na współpracę z tego typu organizacjami, wystapił w przypadku powiatów, a w następnej kolejności gmin miejskich (odpowiednio $27,3 \%$ oraz $17,9 \%$ wskazań). Cieszyć powinien wysoki odsetek organizacji, które deklarują w swoich działaniach aktywizowanie społeczności lokalnych. Propagowanie aktywności i pomoc w podejmowaniu konkretnych działań, zarówno przez pojedynczych mieszkańców danej jednostki samorządowej, jak i całe grupy tworzące się w celu rozwiązania pojawiającego się $\mathrm{w}$ danym momencie problemu, czy zaspokojenia potrzeby jest ze wszech miar wskazane. Sprzyja to budowie kapitału społecznego tego terytorium, ale i podnoszeniu umiejętności indywidualnych jego mieszkańców.

\footnotetext{
${ }^{22}$ Podstawowe obszary działań organizacji pozarządowych w Polsce: sport, turystyka i rekreacja $-38 \%$, kultura i sztuka $17 \%$, edukacja i wychowanie $-14 \%$, ochrona zdrowia $-6 \%$. Zob. J. Przewłocka, Polskie organizacje pozarzqdowe 2012, Stowarzyszenie Klon/Jawor, Warszawa 2013, s. 3. Publikacja dostępna w wersji elektronicznej pod adresem: http://civicpedia.ngo.pl/ files/civicpedia.pl/public/FaktyNGO_broszura_full.pdf(Dostęp: 05.06.2013).
} 
Wykres 1. Obszary działalności organizacji pozarządowych współpracujących $z$ badanymi jst (174=100\%)

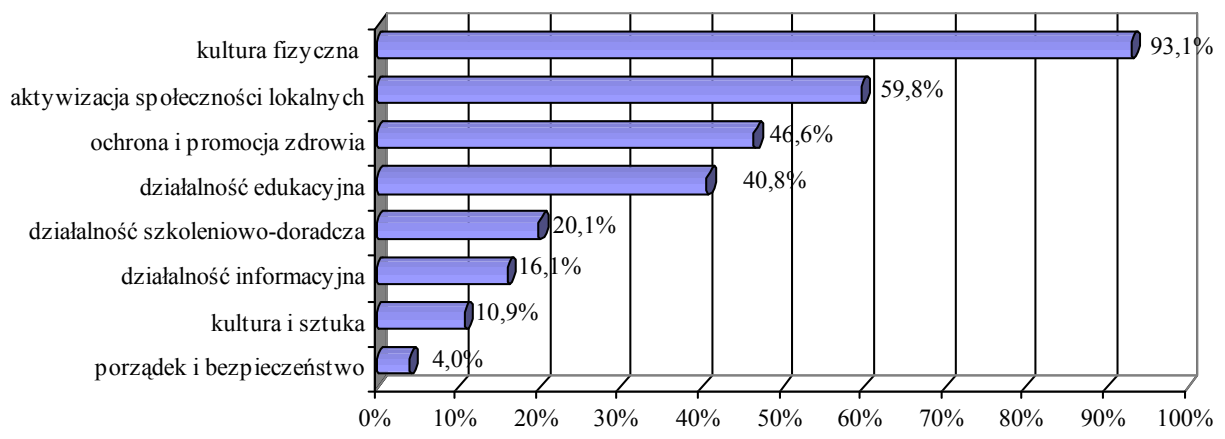

* opcje „kultura i sztuka” oraz „porządek i bezpieczeństwo” zostały wyodrębnione w wyniku analizy odpowiedzi „inne - jakie?”

Źródło: opracowanie własne.

Współpraca samorządów terytorialnych $\mathrm{z}$ organizacjami pozarządowymi może przybierać bardzo różne formy, zarówno te, w których chodzi o pomoc (najczęściej w wymiarze finansowym), w realizacji przez organizacje pozarządowe zadań o charakterze społecznie użytecznym (np. powierzanie realizacji zadań publicznych, czy udzielanie przez samorządy poręczeń dla organizacji realizujących takie zadania), jak i związane z wymianą informacji, czy wspólnym tworzeniem założeń polityki odnoszącej się do działalności różnych podmiotów (w tym organizacji pozarządowych), polegającej na rozwiązywaniu problemów społecznych (np. tworzeniu wspólnych zespołów doradczych i inicjatywnych).

Badane samorządy najchętniej (bez względu na obszar działalności) współpracują $\mathrm{z}$ organizacjami pozarządowymi, wspierając finansowo realizację przez nie zadań o charakterze publicznym oraz wymieniając $\mathrm{z}$ nimi informacje dotyczące ustalonych priorytetów, planowanych działań, czy opracowywanych programów. Co ciekawe, w przypadku współpracy z podmiotami zajmującymi się działalnością doradczo-szkoleniową, informacyjna, czy edukacyjna, częściej dochodzi do wymiany informacji o podejmowanych przez obie strony działaniach, niż do pomocy w realizacji przez organizacje pozarządowe zadań publicznych. To może sugerować, że tego typu organizacje mają możliwość i w praktyce znacznie częściej korzystają z innych źródeł finansowania swojej działalności. Są to np. środki przekazywane im przez prywatne osoby, czy podmioty gospodarcze korzystające $\mathrm{z}$ oferty szkoleniowej, czy związanej $\mathrm{z}$ dostarczaniem informacji umożliwiających, bądź tylko usprawniających proces transferu technologii ze 
świata nauki do biznesu. Pomijając już te kwestie, wydaje się, że wskazane powyżej obszary aktywności organizacji pozarządowych, w największym stopniu i to w sposób bezpośredni, wpływają na poprawę jakości kapitału ludzkiego, podnosząc wiedzę, umiejętności i kompetencje zawodowe osób zamieszkujących daną jednostkę terytorialną. Oczywiście można powiedzieć, że krzewienie kultury fizycznej i zdrowego stylu życia, zgodnie z rzymską maksymą „w zdrowym ciele, zdrowy duch" jest również istotne. Zdrowa dieta, regularna aktywność fizyczna, odpowiednio długi i komfortowy sen, to przecież czynniki wpływające na możliwości percepcyjne człowieka, czy jego wydajność (zarówno fizyczną, jak i intelektualna).

Wracając jednak do form współpracy jednostek samorządowych z funkcjonującymi na ich terenie organizacjami pozarządowymi, dziwi stosunkowo rzadkie powierzanie organizacjom przez samorządy realizacji spoczywających na nich zadań publicznych. To może niestety sugerować, że jst nie są przesadnie zainteresowane dzieleniem się częścią swoich kompetencji z innymi podmiotami, mogącymi działać na rynku usług publicznych. Szkoda również, że badane gminy i powiaty tak rzadko podejmują wspólne działania, tworząc i współpracując w ramach zespołów doradczych i inicjatywnych, czy angażując się w realizację projektów partnerskich. Wydaje się, że wina nie leży tylko po stronie władz samorządowych, ale i samych organizacji. Takie działania (zwłaszcza forma umów partnerskich na realizacje wspólnych projektów) wymagają chęci i umiejętności działania w niejednorodnej grupie, koordynacji działań zarówno na etapie opracowywania koncepcji projektu, jak i późniejszego wdrażania tych ustaleń w czyn.

$\mathrm{Na}$ koniec warto wspomnieć jeszcze o zróżnicowaniu popularności niektórych form współpracy ze względu na typ jednostki poddawanej badaniu. Wzajemne informowanie się o planowanych działaniach, realizacji projektów oraz tworzenie wspólnych zespołów doradczych i inicjatywnych, to zdecydowanie domena gmin miejskich i powiatów. $Z$ kolei realizacja projektów partnerskich jest równie popularna $\mathrm{w}$ gminach miejskich, jak i typowo wiejskich. Przypadek powierzania realizacji zadań organizacjom pozarządowym cieszy się natomiast największym uznaniem wśród gmin miejsko-wiejskich, a wspierania realizacji zadań wśród gmin miejskich. W tym miejscu warto zaznaczyć, że gminy miejskie proporcjonalnie najczęściej korzystają z większości omawianych form współpracy, bez względu na obszar działalności. 


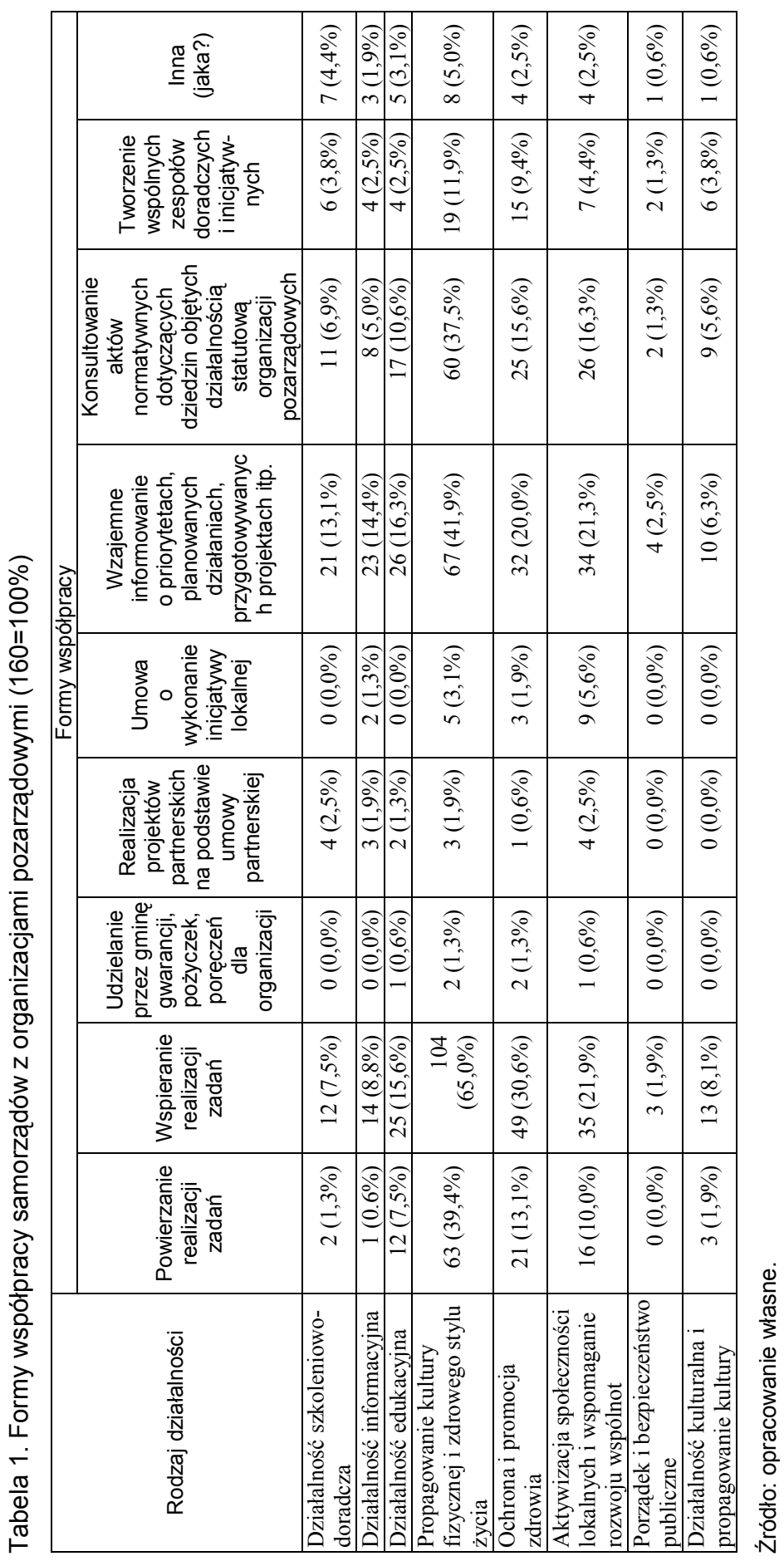


Z pewnością nikt nie ma wątpliwości, że samorządy terytorialne nie są zainteresowane rozpoczynaniem lub kontynuowaniem współpracy $\mathrm{z}$ organizacjami pozarządowymi, których działalność oceniają (na podstawie własnego doświadczenia lub tylko informacji uzyskanych od innego samorządu, czy z innej instytucji) źle lub niewystarczająco dobrze. Niestety obszary działań, jak to już zostało wcześniej określone, najbardziej charakterystyczne, najczęściej utożsamiane z budowaniem, czy podnoszeniem poziomu kapitału ludzkiego na określonym terytorium, są przez badanych przedstawicieli władz samorządowych oceniane najgorzej. W aktualnej skali szkolnej (oceny od 1 do 6), zarówno szeroko rozumiana działalność szkoleniowo-doradcza, jak i informacyjna, czy edukacyjna są oceniane dużo poniżej oceny dobrej (odpowiednio dla wskazanych obszarów średnia waha się od 3,25 do 3,67). Z kolei najwyżej ocenione zostały: działalność kulturalna oraz związana z propagowaniem kultury i sztuki oraz z krzewieniem kultury fizycznej i zdrowego stylu życia. W tych przypadkach średnia ocen była bliska bardzo dobrej, a dominanta wynosi właśnie 5 .

Tabela 2. Struktura ocen działalności organizacji pozarządowych w wybranych obszarach

\begin{tabular}{|l|r|r|r|r|c|c|c|}
\hline \multirow{2}{*}{ Obszar działań } & \multicolumn{7}{|c|}{ Ocena } \\
\cline { 2 - 8 } & 1 & 2 & 3 & 4 & 5 & 6 & średnia \\
\hline $\begin{array}{l}\text { Działalność szkoleniowo-doradcza } \\
(48=100 \%)\end{array}$ & $16,7 \%$ & $16,7 \%$ & $14,6 \%$ & $35,4 \%$ & $10,4 \%$ & $6,3 \%$ & 3,25 \\
\hline $\begin{array}{l}\text { Działalność informacyjna } \\
(53=100 \%)\end{array}$ & $9,4 \%$ & $17,0 \%$ & $20,8 \%$ & $37,7 \%$ & $13,2 \%$ & $1,9 \%$ & 3,34 \\
\hline Działalność edukacyjna (69=100\%) & $4,3 \%$ & $13,0 \%$ & $21,7 \%$ & $39,1 \%$ & $15,9 \%$ & $5,8 \%$ & 3,67 \\
\hline $\begin{array}{l}\text { Propagowanie kultury fizycznej } \\
\text { i zdrowego stylu życia (152=100\%) }\end{array}$ & $0,7 \%$ & $0,0 \%$ & $7,2 \%$ & $29,6 \%$ & $40,8 \%$ & $21,7 \%$ & 4,75 \\
\hline $\begin{array}{l}\text { Ochrona i promocja zdrowia } \\
\text { (81=100\%) }\end{array}$ & $3,7 \%$ & $7,4 \%$ & $14,8 \%$ & $28,4 \%$ & $27,2 \%$ & $18,5 \%$ & 4,23 \\
\hline $\begin{array}{l}\text { Aktywizacja społeczności lokal- } \\
\text { nych i wspomaganie rozwoju } \\
\text { wspólnot (85=100\%) }\end{array}$ & $2,4 \%$ & $15,3 \%$ & $11,8 \%$ & $32,9 \%$ & $25,9 \%$ & $11,8 \%$ & 4,00 \\
\hline $\begin{array}{l}\text { Porządek i bezpieczeństwo } \\
\text { publiczne (5=100\%) }\end{array}$ & $0,0 \%$ & $0,0 \%$ & $40,0 \%$ & $20,0 \%$ & $20,0 \%$ & $20,0 \%$ & 4,20 \\
\hline $\begin{array}{l}\text { Działalność kulturalna } \\
\text { i propagowanie kultury (15=100\%) }\end{array}$ & $0,0 \%$ & $0,0 \%$ & $13,3 \%$ & $13,3 \%$ & $53,3 \%$ & $20,0 \%$ & 4,80 \\
\hline
\end{tabular}

Źródło: opracowanie własne.

Analizując wyniki omawianych powyżej odpowiedzi pod kątem typu badanych jednostek samorządu terytorialnego, można zauważyć pewne ciekawe zależności. Jeśli chodzi o działalność doradczo-szkoleniową, to w gminach wiejskich mamy do czynienia z najbardziej równomiernym rozłożeniem wskazywanych ocen.: $36,3 \%$ przypadło na oceny niskie (1-2), kolejne $36,4 \%$ na oceny 
przeciętne (3-4), a 27,3\% gmin wiejskich oceniło działania organizacji pozarządowych bardzo dobrze (oceny 5-6). Statystycznie najgorzej organizacje pozarządowe działające w omawianym obszarze oceniają gminy miejsko-wiejskie $(57,2 \%$ ocen $1-2)$. $Z$ kolei powiaty najczęściej podają oceny przeciętne $(81,8 \%$ ocen 3-4). Największy odsetek ocen bardzo dobrych wystapił natomiast w omawianej już grupie gmin wiejskich. Wśród gmin wiejskich jest także największy odsetek ocen bardzo dobrych, odnoszących się do działalności informacyjnej organizacji pozarządowych, funkcjonujących na terenach badanych jednostek $(24,0 \%)$. Ponownie $\mathrm{w}$ grupie powiatów dominują oceny przeciętne $(72,7 \%)$, a w gminach miejskich proporcjonalnie najwięcej jest ocen złych $(40,0 \%)$. Co więcej, w gminach miejskich i miejsko-wiejskich, badani ani razu nie dali działającym w tym obszarze organizacjom ocen bardzo dobrych.

W przypadku działalności edukacyjnej, tak jak przy działalności informacyjnej, wyróżniają się gminy wiejskie, w ramach których występuje zarówno najwyższy odsetek ocen dobrych $(31,2 \%)$, jak i złych $(34,4 \%)$. W pozostałych typach jst dominują oceny przeciętne, których odsetek waha się w granicach od $84,6 \%$ dla gmin miejskich, do $90,0 \%$ dla powiatów. Podobnie rzecz ma się $\mathrm{z}$ oceną działań organizacji pozarządowych w zakresie ochrony i promocji zdrowia. Tym razem jednak wyróżniają się gminy miejsko-wiejskie, w których występuje największy odsetek zarówno ocen dobrych $(66,6 \%)$, jak i złych $(17,1 \%)$. $\mathrm{W}$ pozostałych typach jst dominują oceny przeciętne. Wysoka ocena działań zmierzających do aktywizacji społeczności lokalnych, to z kolei domena organizacji pozarządowych funkcjonujących $\mathrm{w}$ badanych gminach miejskich $(44,4 \%$ ocen 5-6), a powodu do dumy nie mają w tej kwestii gminy miejsko-wiejskie $(30,0 \%$ ocen złych $-1-2)$.

Jak to już zostało wcześniej wspomniane, działalność organizacji w obszarze propagowania kultury fizycznej i zdrowego stylu życia jest oceniana przez prawie wszystkich bardzo wysoko. Poza gminami miejskimi, gdzie dominanta wyniosła 4 , w pozostałych przypadkach dominują oceny bardzo dobre, osiagając w gminach miejsko-wiejskich poziom $75,1 \%$. Tylko w przypadku jednej gminy wiejskiej pojawiła się ocena zła.

Działalność organizacji pozarządowych (zwłaszcza tych ocenianych wysoko) powinna przynosić określone korzyści zarówno badanym jednostkom samorządu terytorialnego, funkcjonującym na ich terenie organizacjom, jak i mieszkańcom tych gmin. Biorąc pod uwagę korzyści dla badanych jst, to najczęściej wskazywane były większe kompetencje organizacji pozarządowych i osób w nich pracujących, pozwalające im lepiej zaspokajać pojawiające się potrzeby społeczne. To z kolei ma wpływ na poprawę jakości życia mieszkańców badanych jst. Istnienie organizacji pozarządowych pozwala również świadczyć usługi, których istniejące i należące do gmin, czy powiatów jednostki organizacyjne nie byłyby w stanie zrealizować. Nawet tam, gdzie funkcjonują już wyspecjali- 
zowane podmioty świadczące tego typu usługi, zwiększa się dzięki istnieniu organizacji pozarządowych dostępność do tych usług. Nie bez znaczenia jest także oszczędność finansowa. Organizacje pozarządowe są w stanie zrealizować stawiane przed nimi zadania taniej, niż miałoby to miejsce w przypadku podmiotów publicznych, czy komercyjnych. Dzieje się tak między innymi dlatego, że dość często organizacje korzystają z pracy wolontariuszy, a ilość osób zaangażowanych bezpośrednio $\mathrm{w}$ proces świadczenia usługi jest proporcjonalnie większa, niż w przypadku innych podmiotów, które nierzadko w swojej strukturze organizacyjnej mają nadmiernie rozbudowany pion zarządczo-administracyjny.

Wykres 2. Korzyści dla badanych jednostek samorządu terytorialnego ze współpracy $z$ organizacjami pozarządowymi $(146=100 \%)$

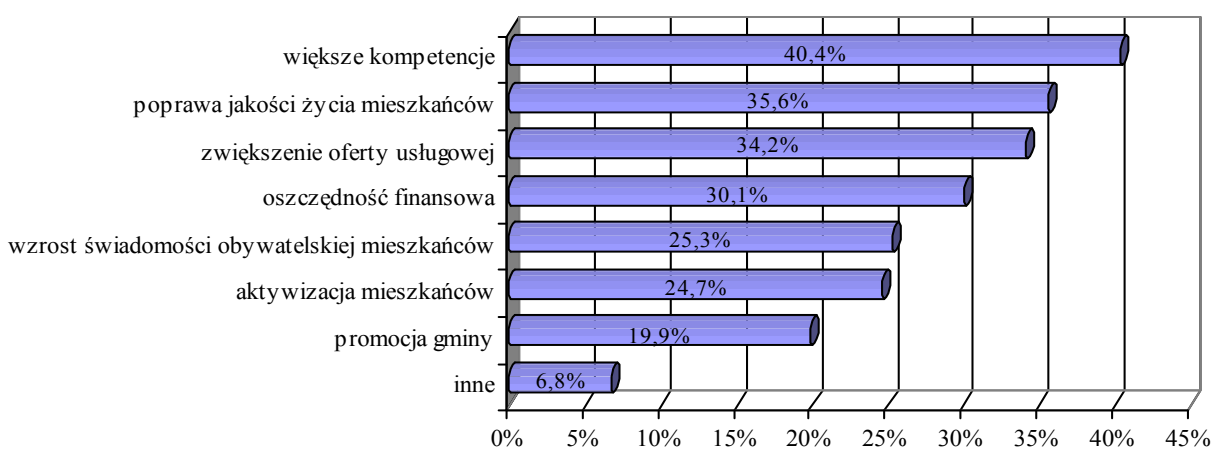

Źródło: opracowanie własne.

Trzeba jednak w tym miejscu zaznaczyć, że na tego rodzaju korzyść zdecydowanie częściej wskazywały gminy miejskie. W następnej kolejności gminy miejsko-wiejskie, a prawie trzykrotnie rzadziej w stosunku do gmin miejskich, gminy wiejskie. To mogłoby sugerować, że organizacje pozarządowe funkcjonujące $\mathrm{w}$ większych miejscowościach działają taniej, niż ich odpowiedniki prowadzące swoją działalność w małych miejscowościach i na terenach wiejskich. Być może wynika to jednak z niższych niż w dużych miejscowościach kosztów świadczenia usług przez podmioty własne lub inne podmioty publiczne, czy prywatne. Jednak, aby móc jednoznacznie wyjaśnić tę sprawę, należałoby przeprowadzić dodatkowe badania koncentrujące się na kwestiach efektywności podmiotów, zaangażowanych w procesy świadczenia usług publicznych. 
Spośród najczęściej wymienianych korzyści dla samych organizacji pozarządowych, wynikających z podejmowania współpracy, badane jst wymieniały przede wszystkim wsparcie finansowe (ponad połowa badanych samorządów). W tym miejscu warto też wspomnieć o trzeciej w kolejności (pod względem częstotliwości wskazań) korzyści, która może być w dużym stopniu powiązana ze wsparciem finansowym. Chodzi o motywację do lepszego działania. Wydaje się, że chęć skorzystania ze środków publicznych, którymi dysponują gminy i powiaty, może być argumentem, który wpływa na świadomość, czy chęć poprawy sposobu i zasad funkcjonowania organizacji pozarządowej. We wspomnianych już raportach Stowarzyszenia Klon/Jawor problemy finansowe należą do najistotniejszych, z punktu widzenia możliwości funkcjonowania i rozwoju organizacji pozarządowych działających w Polsce (szczególnie tych małych, których charakter odziaływania nie wykracza poza zasięg lokalny). Szansa i chęć poprawy sytuacji finansowej może więc być dla nich bardzo atrakcyjną pokusą i źródłem mobilizacji do lepszego działania, zgodnego z oczekiwaniami dysponujących tymi środkami jednostek samorządu terytorialnego, na terenie których prowadzą swoją działalność.

Korzyścią, na którą badani wskazywali w drugiej kolejności było wsparcie merytoryczne i organizacyjne ze strony samorządów. Trudno powiedzieć, na ile jest to rzeczywista i częsta korzyść. Trudno wyobrazić sobie sytuację, w której badane samorządy terytorialne są w stanie pomóc pod tym względem istniejącym już od dłuższego czasu organizacjom, które zdążyły nabyć potrzebne doświadczenie i na dobre zaistnieć na rynku. Jednak w przypadku organizacji nowotworzonych lub takich, które dopiero zaczynają rozwijać swoje skrzydła pomoc merytoryczna i organizacyjna ze strony samorządów może okazać się nieocenionym i bardzo pożądanym źródłem wiedzy o rozwiązaniach, pozwalających coraz sprawniej radzić sobie w praktyce. Warunek jest tylko jeden, że odpowiednie osoby, czy całe komórki odpowiedzialne w samorządach za współpracę, posiadają odpowiednie kompetencje. Przeanalizowane w dalszej części tekstu wyniki badań, przeprowadzonych wśród organizacji pozarządowych funkcjonujących na terenie województwa łódzkiego, pozostawiają pod tym względem pewne wątpliwości.

Zdaniem badanych, nie bez znaczenia pozostaje fakt możliwości skorzystania z działań promocyjnych realizowanych przez samorządy terytorialne, które swoim słowem, opinią, a przede wszystkim podjęciem decyzji o współpracy uwiarygadniają działalność organizacji pozarządowych. Oprócz tego, nie można oczywiście zapominać o właściwych działaniach promocyjnych podejmowanych przez samorządy, w ramach których propagowane są idee społeczeństwa obywatelskiego, aktywizacji i partycypacji społecznej, których przejawami jest swoją drogą istnienie organizacji pozarządowych i ich współpraca z samorządami. 
Dziwi trochę niski odsetek wskazań na wsparcie lokalowe, gdyż dla organizacji nie dysponujących własnym lokalem, możliwość nieodpłatnego lub na preferencyjnych warunkach skorzystania z lokalu będącego własnością samorządu jest swego rodzaju formą wsparcia finansowego, tak potrzebnego dla większości małych, działających na poziomie lokalnym organizacji pozarządowych. Tym dziwniejsza jest sytuacja, w której to głównie powiaty, a w następnej kolejności gminy miejskie wskazują na tego typu korzyść. W przypadku gmin miejsko-wiejskich i wiejskich tego typu wskazań jest proporcjonalnie przynajmniej o połowę mniej.

Wykres 3. Korzyści dla organizacji pozarządowych wynikające ze współpracy z badanymi jednostkami samorządu terytorialnego $(142=100 \%)$

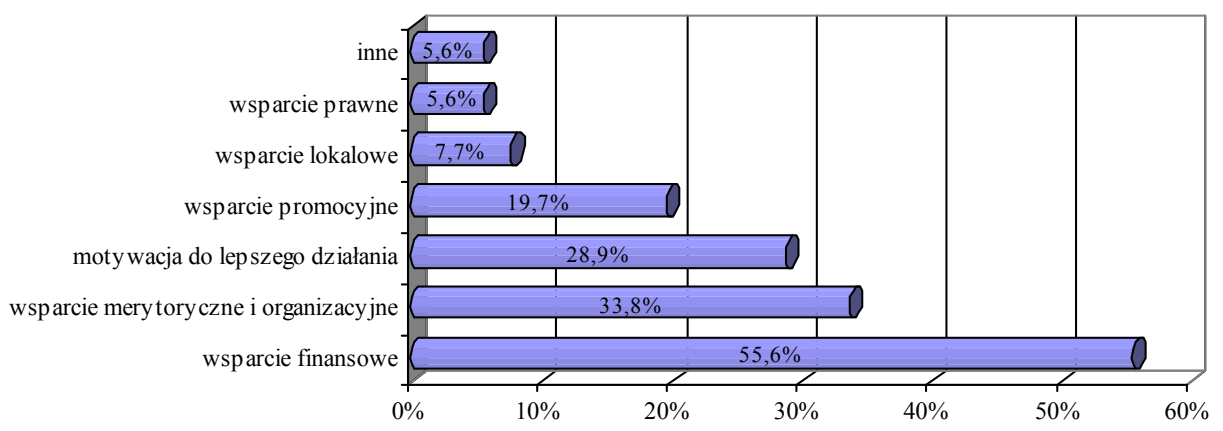

Źródło: opracowanie własne.

Główną korzyścią dla mieszkańców, na którą wskazuje prawie $2 / 3$ badanych jst jest ich aktywizacja, którą wskazywali już wcześniej jako jedną z korzyści płynących z funkcjonowania tego typu organizacji pozarządowych na zarządzanym przez nich terytorium. Zaktywizowanie mieszkańców do podejmowania działań, realizacji pomysłów leżących w ich wspólnym interesie powinno się przełożyć nie tylko na wzrost świadomości obywatelskiej i zaangażowanie $\mathrm{w}$ procesy decyzyjne związane $\mathrm{z}$ rozwojem jednostki terytorialnej, w ramach której przyszło im funkcjonować, ale również na podejmowanie inicjatyw, dzięki którym będą starali realizować i rozwijać swoje zainteresowania, czy umiejętności. To z kolei powinno wpłynąć z czasem na wzrost poziomu kapitału ludzkiego pojedynczej gminy, powiatu, a $\mathrm{z}$ czasem nawet całego województwa. Zdaniem badanych, aktywizowanie mieszkańców wokół problemów, na które 
napotykają powinno wpłynąć również pozytywnie na ich poziom zintegrowania, świadomości tworzenia lokalnej wspólnoty.

Kolejna grupa korzyści koncentruje się wokół większej dostępności do usług publicznych, w których realizację zaangażowane są organizacje pozarządowe. Chodzi tutaj zarówno o zwiększenie oferty usług, jak i będący tego konsekwencją wzrost liczby potencjalnych odbiorców usług oraz większą łączną liczbę podmiotów świadczących usługi określonego rodzaju.

Wykres 4. Korzyści dla mieszkańców wynikające ze współpracy badanych jednostek samorządu terytorialnego $z$ organizacjami pozarządowymi $(144=100 \%)$

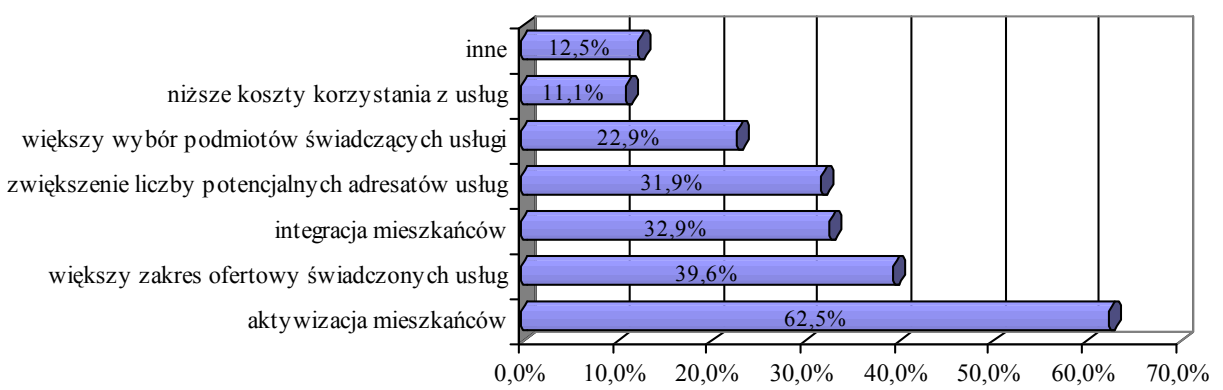

Źródło: opracowanie własne.

Dziwić może niski odsetek badanych jst, które wskazały na korzyści finansowe dla mieszkańców, wynikające $\mathrm{z}$ niższych kosztów usług świadczonych przez organizacje pozarządowe, tym bardziej, że w pytaniu dotyczącym korzyści dla samorządów kwestia oszczędności była wskazywana zdecydowanie częściej. Może to oczywiście sugerować, że część samorządów, wykorzystując działalność organizacji pozarządowych, oszczędza na kosztach świadczenia usług, ale nie obniżając opłat za nie, zaoszczędzone środki przeznacza natomiast na realizację innych, nałożonych ustawowo na gminy i powiaty zadań. Wydaje się jednak, że to chyba zbyt daleko idące uproszczenie wyjaśniania tej sprawy.

Podejmowanie współpracy przez badane jednostki samorządu terytorialnego napotyka oczywiście na różnorodne bariery, jednak najważniejszą z nich (zdecydowanie najczęściej wskazywaną) jest bariera finansowa, przejawiająca się w niewystarczającej ilości lub w najgorszym przypadku braku środków, które samorządy chcą lub mogą przeznaczyć na współpracę. Na brak środków narzeka prawie $90 \%$ badanych jednostek. Nie powinno to być oczywiście żadnym wielkim zaskoczeniem wobec docierających dość regularnie informacji o kłopotach 
finansowych polskich samorządów, problemach z utrzymaniem się przez nie w ryzach ustalonych przepisami prawa, dotyczącego zasad budżetowych.

Tabela 3. Główne bariery współpracy pomiędzy badanymi samorządami, a organizacjami pozarządowymi $(156=100 \%)$

\begin{tabular}{|l|c|c|}
\hline \multicolumn{1}{|c|}{ Rodzaj bariery } & Liczba & Udział \\
\hline $\begin{array}{l}\text { Brak/niewystarczająca ilość środków, które mogłyby zostać prze- } \\
\text { znaczone przez samorządy na współpracę }\end{array}$ & 137 & $87,8 \%$ \\
\hline Brak zaufania do samorządów ze strony organizacji pozarządowych & 3 & $1,9 \%$ \\
\hline $\begin{array}{l}\text { Ograniczone zaufanie do samorządów ze strony organizacji poza- } \\
\text { rządowych }\end{array}$ & 9 & $5,8 \%$ \\
\hline Brak zaufania do organizacji pozarządowych ze strony samorządów & 3 & $1,9 \%$ \\
\hline $\begin{array}{l}\text { Ograniczone zaufanie do organizacji pozarządowych ze strony } \\
\text { samorządów }\end{array}$ & 26 & $16,7 \%$ \\
\hline Brak woli współpracy ze strony organizacji pozarządowych & 30 & $19,2 \%$ \\
\hline Brak woli współpracy ze strony samorządów & 29 & $18,6 \%$ \\
\hline $\begin{array}{l}\text { Traktowanie organizacji pozarządowych, jako konkurenta dla pod- } \\
\text { miotów należących do samorządów }\end{array}$ & 3 & $1,9 \%$ \\
\hline $\begin{array}{l}\text { Traktowanie organizacji pozarządowych wyłącznie/główne jako } \\
\text { petenta, chcącego skorzystać ze środków publicznych }\end{array}$ & 3 & $1,9 \%$ \\
\hline Niskie kompetencje pracowników organizacji pozarządowych & 16 & $10,3 \%$ \\
\hline Niski potencjał organizacyjny organizacji pozarządowych & 4 & $2,6 \%$ \\
\hline Inne & 6 & $3,8 \%$ \\
\hline Brak barier & 5 & $5,9 \%$ \\
\hline
\end{tabular}

Źródło: opracowanie własne.

Cieszy natomiast niski odsetek wskazań, dotyczących słabego potencjału organizacyjnego funkcjonujących na terenie badanych jednostek organizacji pozarządowych, a także traktowania podmiotów należących do trzeciego sektora, jako petenta wyciagającego jedynie ręce po środki publiczne (nie oferując praktycznie nic w zamian), czy konkurencji dla funkcjonujących na rynku usług publicznych podmiotów należących do samorządów (chociaż w tym przypadku może to po prostu oznaczać brak podmiotów samorządowych, działających w danym obszarze usług).

Niepokoi z kolei wskazywany w prawie co piątym badanym samorządzie brak woli współpracy ze strony samorządów, jak i organizacji pozarządowych. Trzeba jednak w tym miejscu zaznaczyć, że o ile wskazanie na brak woli współpracy ze strony samorządów jest ich swoistą deklaracją potwierdzającą stan faktyczny, to brak woli współpracy ze strony podmiotów trzeciego sektora jest już tylko domniemaniem ich intencji. Takie stwierdzenie jest tym bardziej uzasadnione, że na nieufność organizacji pozarządowych w stosunku do jst wskazu- 
je ponad dwa razy mniej badanych samorządów niż w odniesieniu do sytuacji odwrotnej, a więc nieufności organizacji wobec samorządów. A przecież bez wzajemnego zaufania trudno o współpracę, jej nawiązywanie i rozwój.

\section{Współpraca organizacji trzeciego sektora z jednostkami samorządu terytorialnego w zakresie rozwoju kapitału ludzkiego w regionie łódzkim}

$\mathrm{Na}$ potrzeby badań przeprowadzonych wśród organizacji pozarządowych, których funkcjonowanie powinno przyczyniać się do poprawy jakości kapitału ludzkiego w poszczególnych gminach, powiatach, a w konsekwencji i całego województwa skorzystano z bazy adresowej wybranych, aktywnych podmiotów gospodarki narodowej. W pierwszym etapie selekcji wyodrębniono, według wybranych form prawnych oraz sekcji Polskiej Klasyfikacji Działalności 2007 (zob. tabela 4), 5162 podmioty zarejestrowane w systemie REGON. Na potrzeby badań zdecydowano się na przyjęcie szerokiej definicji organizacji pozarządowych, uwzględniającej nie tylko stowarzyszenia i fundacje, ale i inne podmioty nie należące do sektora publicznego, czy komercyjnego, których działalność nie jest nastawiona głównie na generowanie zysku, a na zaspokajanie określonych potrzeb określonych grup społecznych, czy zawodowych. W ramach tych form prawnych zdecydowano się na pozostawienie podmiotów, które ze względu na rodzaj prowadzonej działalności mogą się przyczyniać do kreowania i podnoszenia poziomu kapitału ludzkiego w ramach określonego terytorium.

Tabela 4. Zestawienie liczbowe podmiotów gospodarki narodowej zarejestrowanych w systemie REGON, wg wybranych form prawnych oraz sekcji PKD 2007 (stan na dzień 31.03.2011 r.)

\begin{tabular}{|c|l|c|}
\hline & \multicolumn{1}{|c|}{ Forma prawna } & llość podmiotów \\
\hline $\mathbf{1}$ & Fundacje & 640 \\
\hline $\mathbf{2}$ & Stowarzyszenia & 2750 \\
\hline $\mathbf{3}$ & Kościół Katolicki & 4 \\
\hline $\mathbf{4}$ & Inne kościoły i związki wyznaniowe & 0 \\
\hline $\mathbf{5}$ & Związki zawodowe & 1328 \\
\hline $\mathbf{6}$ & Organizacje pracodawców & 18 \\
\hline $\mathbf{7}$ & Samorząd gospodarczy i zawodowy & 422 \\
\hline $\mathbf{8}$ & Razem & $\mathbf{5 1 6 2}$ \\
\hline
\end{tabular}


Tabela 4 (cd.)

\begin{tabular}{|c|l|c|}
\hline PKD7 & \multicolumn{1}{|c|}{ Nazwa } & Ilość \\
\hline $\mathbf{6 9}$ & $\begin{array}{l}\text { Działalność prawnicza, rachunkowo księgowa i doradztwo podat- } \\
\text { kowe }\end{array}$ & 4 \\
\hline $\mathbf{7 0 2}$ & Doradztwo związane z zarządzaniem & 5 \\
\hline $\mathbf{7 1 2}$ & Badania i analizy techniczne & 2 \\
\hline $\mathbf{7 2}$ & Badania naukowe i prace rozwojowe & 2 \\
\hline $\mathbf{7 4 9}$ & $\begin{array}{l}\text { Pozostała działalność profesjonalna, naukowa i techniczna, gdzie } \\
\text { indziej niesklasyfikowana }\end{array}$ & 0 \\
\hline $\mathbf{8 2 1}$ & $\begin{array}{l}\text { Działalność związana z administracyjną obsługą biura, włączając } \\
\text { działalność wspomagająca }\end{array}$ & 1 \\
\hline $\mathbf{8 2 3}$ & Działalność związana z organizacją targów, wystaw i kongresów \\
\hline $\mathbf{8 2 9 9 Z}$ & $\begin{array}{l}\text { Pozostała działalność wspomagająca prowadzenie działalności } \\
\text { gospodarczej, gdzie indziej niesklasyfikowana }\end{array}$ & 62 \\
\hline $\mathbf{8 5 5 1 Z}$ & $\begin{array}{l}\text { Pozaszkolne formy edukacji sportowej oraz zajęć sportowych i } \\
\text { rekreacyjnych }\end{array}$ & 3 \\
\hline $\mathbf{8 5 5 2 Z}$ & Pozaszkolne formy edukacji artystycznej & 2 \\
\hline $\mathbf{8 5 5 9}$ & Nauka języków obcych & 581 \\
\hline $\mathbf{8 5 6}$ & Działalność wspomagająca edukację & 1323 \\
\hline $\mathbf{9 4 1}$ & $\begin{array}{l}\text { Działalność organizacji komercyjnych, pracodawców oraz orga- } \\
\text { nizacji profesjonalnych }\end{array}$ & 3171 \\
\hline $\mathbf{9 4 2}$ & Działalność związków zawodowych & $\mathbf{5 1 6 2}$ \\
\hline $\mathbf{9 4 9 9 Z}$ & $\begin{array}{l}\text { Działalność pozostałych organizacji członkowskich, gdzie indziej } \\
\text { niesklasyfikowana }\end{array}$ & 2 \\
\hline & Razem & 2 \\
\hline
\end{tabular}

Źródło: opracowanie własne na podstawie danych Urzędu Statystycznego w Łodzi.

Po analizie poszczególnych przypadków, do dalszych badań wybrano 982 organizacje pozarządowe, których działalność powinna odpowiadać założeniom badania. Na rozesłaną ankietę odpowiedziało w sumie 160 organizacji pozarządowych (zwrotność na poziomie 17,96\%), przy czym 5 z nich zakończyło wypełnianie kwestionariusza już po udzieleniu odpowiedzi na pierwsze pytanie, które weryfikowało ich możliwości uczestnictwa w procesach podnoszenia kapitału ludzkiego, poprzez rodzaj podejmowanych przez badane organizacje działań. Trzeba jednak w tym miejscu dodać, że dodatkowo ok. 180 kopert $\mathrm{z}$ ankietami wróciło z informacją ,,adresat nieznany” lub ,adresat wyprowadził się”. To stanowi ok. $20 \%$ wszystkich wysłanych ankiet. Niestety jest to najlepszy dowód na to, że aktualność danych generowanych przez Urzędy Statystyczne nadal pozostawia wiele do życzenia. Co gorsza, takie sytuacje miały kilkukrotnie miejsce w odniesieniu do organizacji, które figurowały na oficjalnych listach podmiotów trzeciego sektora, z którymi rzekomo współpracowały badane samorządy. To daje wiele do myślenia, już nie tylko pod kątem aktualności i wiarygodności danych posiadanych przez samorządy, ale i pod kątem zarządzania 
środkami publicznymi przeznaczonymi na współpracę. Nie można przecież wykluczyć sytuacji, w której dochodzi do przekazania jakiejś pomocy finansowej podmiotowi, który w praktyce nie prowadzi żadnej działalności.

Tabela 5. Obszary działalności badanych organizacji pozarządowych (155=100\%)

\begin{tabular}{|l|c|c|}
\hline \multicolumn{1}{|c|}{ Rodzaj działań } & Liczba & Udział \\
\hline Działalność szkoleniowo-doradcza & 42 & $27,1 \%$ \\
\hline Działalność informacyjna & 34 & $21,9 \%$ \\
\hline Działalność edukacyjna & 68 & $43,9 \%$ \\
\hline Propagowanie kultury fizycznej i zdrowego stylu życia & 40 & $25,8 \%$ \\
\hline Ochrona i promocja zdrowia & 48 & $31,0 \%$ \\
\hline Aktywizacja społeczności lokalnych i wspomaganie rozwoju wspólnot & 72 & $46,5 \%$ \\
\hline $\begin{array}{l}\text { Organizowanie staży zawodowych oraz nadawanie uprawnień i kwali- } \\
\text { fikacji zawodowych }\end{array}$ & 2 & $1,3 \%$ \\
\hline Działalność badawczo-rozwojowa oraz transfer technologii & 4 & $2,6 \%$ \\
\hline $\begin{array}{l}\text { Pomoc dla osób wykluczonych społecznie (w tym aktywizacja zawo- } \\
\text { dowa) }\end{array}$ & 7 & $4,5 \%$ \\
\hline Działalność kulturalna & 7 & $4,5 \%$ \\
\hline
\end{tabular}

Źródło: opracowanie własne.

Spośród podmiotów, które wzięły udział w badaniu, największą grupę stanowiły te, które działały głównie w obszarze aktywizacji społeczności lokalnych i wspomagania rozwoju wspólnot poprzez zwiększanie aktywności indywidualnej i propagowanie wspólnych działań przez członków lokalnej społeczności (46,5\% wszystkich badanych) oraz szeroko rozumianej edukacji - prowadzenie szkół, kształcenie ustawiczne, a także wspieranie zainteresowań/hobby poprzez pozaszkolne formy edukacji $-43,9 \%$ badanych. Ponad 30\% badanych organizacji działało w obszarze ochrony i promocji zdrowia. Przy czym trzeba pamiętać, że około połowy organizacji pozarządowych w Polsce nie ogranicza się do jednego pola, czy obszaru działania ${ }^{23}$.

Zdecydowana większość z badanych podmiotów $(92,9 \%$ ze 155 , które przeszły weryfikację $\mathrm{w}$ postaci pierwszego pytania $\mathrm{z}$ przesłanej do nich ankiety) współpracuje $\mathrm{z}$ jednostkami samorządu terytorialnego, w ramach których prowadzą swoją działalność. Przy czym trzeba dodać, że zdecydowanie częściej

${ }^{23}$ Zob. M. Gumkowska, J. Herbst, P. Radecki, Podstawowe fakty o organizacjach pozarzadowych. Raport z badania 2008, Stowarzyszenie Klon/Jawor, Warszawa 2009, s. 29 oraz J. Przewłocka, P. Adamiak, J. Herbst, Podstawowe fakty o organizacjach pozarzqdowych - raport z badania 2012, Stowarzyszenie Klon/Jawor, Warszawa 2013, s. 16. 
dochodzi do współpracy z gminami, niż powiatami (odpowiednio w 89,7\% ${ }^{24}$ i $62,6 \%$ przypadków). Warto w tym miejscu dodać, że dokładnie $60 \%$ badanych organizacji współpracuje $\mathrm{z}$ samorządem terytorialnym zarówno na poziomie gminy, jak i powiatu, 29,7\% wyłącznie na poziomie gminy, a jedynie 2,6\% wyłącznie na poziomie powiatu.

Badane organizacje poproszone zostały również o wskazanie powodów, dla których nie udało się im podjąć współpracy, czy to z gminami, czy powiatami, ewentualnie w tych nielicznych przypadkach - z żadnym z wcześniej wskazanych poziomów samorządu terytorialnego. Może być pewnym zaskoczeniem, iż badane organizacje wcale nie wskazywały najczęściej na brak środków, w tym finansowych, do rozpoczęcia współpracy. Najczęściej wymieniane były dwie bariery: brak zainteresowania współpracą ze strony samorządów oraz słabość samych organizacji. Niewatpliwie niepokoi wysoki odsetek organizacji, którym nie udało się podjąć współpracy ze względu na brak zainteresowania samorządów. Niestety takie opinie pokrywają się w dużym stopniu z odpowiedziami udzielonymi w tym zakresie przez same samorządy. Nie świadczy to dobrze o otwartości (częściowo wymuszonej przez zapisy wspominanej już ustawy z dnia 23 kwietnia 2003 r.) samorządów na współpracę z podmiotami należącymi do trzeciego sektora. Niestety same organizacje też nie zawsze wykazują zainteresowanie podejmowaniem współpracy z samorządami terytorialnymi, na terenie których prowadzą swoją działalność. Z kolei na docenienie zasługują te spośród organizacji, które miały odwagę przyznać, że brak współpracy z samorządami wynika $\mathrm{z}$ ich własnej słabości. Takie odpowiedzi mogą być typowe dla młodych, dopiero rozpoczynających swoją ,przygodę" podmiotów, ale w oparciu o uzyskane informacje, trudno tę tezę jednoznacznie potwierdzić lub obalić.

Wprawdzie, to stosunkowo niewielki odsetek udzielonych odpowiedzi, ale i tak zasługujący na krótką refleksję. Otóż 9 ze 155 organizacji informuje, że do współpracy nie doszło, gdyż samorządy terytorialne, na obszarze których badane organizacje funkcjonuja, współpracują tylko z ,wybranymi" podmiotami. Wprawdzie obowiązujące przepisy prawne powinny wyeliminować tego typu sytuacje, ale życie pokazuje, że przynajmniej w odczuciu niektórych organizacji pozarządowych dochodzi do sytuacji, w której z nie zawsze zrozumiałych dla nich względów faworyzowane, czy inaczej traktowane są pewne podmioty ${ }^{25}$.

${ }^{24}$ W przywoływanym już raporcie Stowarzyszenia Klon/Jawor z badań za rok 2012 z samorządem terytorialnym na poziomie gminy kontakty utrzymuje $85 \%$ organizacji pozarządowych, przy czym w przypadku 41\% mają one charakter częsty i regularny. Zob. J. Przewłocka, Polskie organizacje pozarzqdowe 2012, Stowarzyszenie Klon/Jawor, Warszawa 2013, s. 12.

${ }^{25} \mathrm{~W}$ dwóch przypadkach udzielający odpowiedzi pozwolili sobie wyraźnie wskazać powody tego faworyzowania. 
Wykres 5. Powody niepodjęcia przez badane podmioty współpracy z jednostkami samorządu terytorialnego $(50=100 \%)$

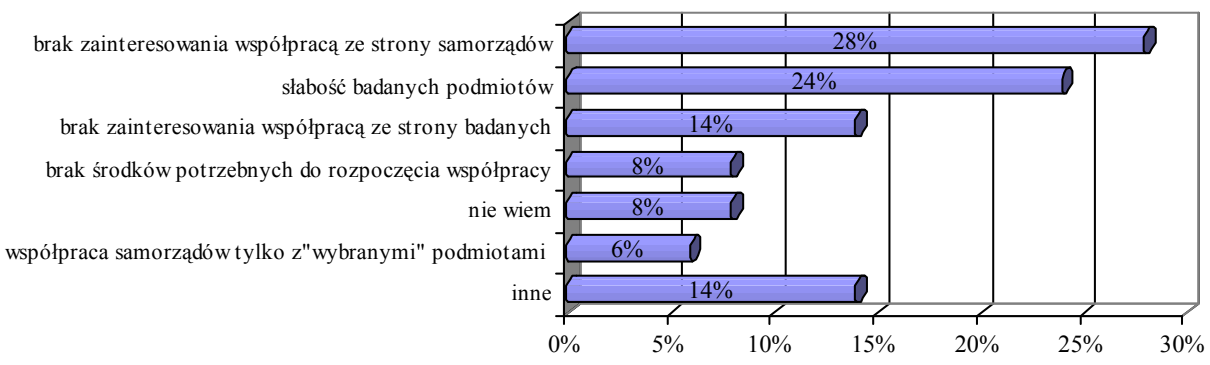

Źródło: opracowanie własne.

Spośród tych organizacji, które współpracują z jednostkami samorządu terytorialnego, ponad połowa $(51,4 \%)$ brała udział w tworzeniu przez którą́ $\mathrm{z}$ jednostek samorządu terytorialnego (gminę, powiat), z którą współpracują aktualnego rocznego lub wieloletniego programu współpracy z organizacjami pozarządowymi. Do najczęściej wskazywanych powodów niepodejmowania udziału w tworzeniu planów współpracy przez pozostałą część badanych organizacji należały:

- brak zaproszenia ze strony jst do udziału w tworzeniu programu 33 (49,3\% nie biorących udziału w tworzeniu planu współpracy);

- brak/niewystarczająca wiedza po stronie organizacji o zasadach i możliwościach podejmowania współpracy z jst - 9 wskazań $(13,4 \%)$;

- brak zainteresowania ze strony samych organizacji - 6 wskazań $(9 \%)$;

- brak/niewystarczająca wiedza po stronie jst o zasadach i możliwościach podejmowania współpracy z organizacjami - 3 wskazania $(4,5 \%)$;

- traktowanie przez jst konsultacji i opinii organizacji, jako „niczego nie wnoszącej konieczności” - 2 wskazania (3\%).

Udział w tworzeniu programu współpracy polegał głównie na konsultacjach przy ustalaniu potrzeb mieszkańców, które mogłyby być zaspokajane poprzez działalność organizacji pozarządowych m.in. poprzez przekazywanie własnych propozycji dotyczących zadań priorytetowych, czy wspólne badania mające na celu ustalenie potrzeb mieszkańców $(57,1 \%$ z 77 organizacji współtworzących programy) oraz konsultacjach przy ustalaniu potrzeb finansowych organizacji pozarządowych, działających $w$ ramach określonego terytorium $(54,5 \%$ organizacji biorących udział w tworzeniu programów współpracy). 
Tabela 6. Zakres działań podejmowanych przez organizacje pozarządowe w ramach współtworzenia programu współpracy $(77=100 \%)$

\begin{tabular}{|l|c|c|}
\hline \multicolumn{1}{|c|}{ Zakres działań } & Liczba & $\%$ \\
\hline $\begin{array}{l}\text { Konsultacje przy ustalaniu potrzeb mieszkańców, które mogłyby być } \\
\text { zaspokajanie poprzez działalność organizacji pozarządowych }\end{array}$ & 44 & $57,1 \%$ \\
\hline $\begin{array}{l}\text { Konsultacje przy ustalaniu potrzeb finansowych organizacji pozarządo- } \\
\text { wych działających w gminie/powiecie }\end{array}$ & 42 & $54,5 \%$ \\
\hline $\begin{array}{l}\text { Konsultacje przy ustalaniu potrzeb pozafinansowych organizacji pozarzą- } \\
\text { dowych działających w gminie/powiecie }\end{array}$ & 35 & $44,9 \%$ \\
\hline Opiniowanie zapisów gotowego projektu programu współpracy & 31 & $40,3 \%$ \\
\hline Tworzenie wybranych podobszarów programu & 2 & $3,7 \%$ \\
\hline Inny & 2 & $3,7 \%$ \\
\hline
\end{tabular}

Źródło: opracowanie własne.

Na pytanie dotyczące ewentualnych zastrzeżeń pod adresem samorządów, które byłyby związane z tworzeniem i późniejszą realizacją programu współpracy z organizacjami pozarządowymi, zdecydowała się odpowiedzieć jedynie połowa (80) badanych organizacji. 26 (32,5\%) spośród nich przyznało, że ma pewne zastrzeżenia $\mathrm{w}$ tym zakresie. Główne zarzuty, jakie padały pod adresem władz samorządowych, to nieuwzględnianie propozycji przedstawianych przez organizacje pozarządowe (13 wskazań), brak realizacji przyjętego programu (4 wskazania) oraz brak konsultacji z organizacjami pozarządowymi (3 wskazania).

Jak to już zostało wcześniej stwierdzone, współpraca organizacji pozarządowych z samorząami terytorialnymi może przybierać bardzo różne formy. Badane organizacje najczęściej (bez wydzielania konkretnego obszaru działalności) współpracują z samorządami terytorialnymi otrzymując wsparcie na realizację swojej działalności, która jest uznawana za społecznie użyteczną (192 wskazania). Do kolejnej grupy można zaklasyfikować wzajemne informowanie się o planowanych działaniach, czy projektach, w których mogą wziąć udział organizacje pozarządowe (118 wskazań), a także tworzenie wspólnych zespołów doradczych i inicjatywnych (106 wskazań). Następna grupa, to z kolei powierzanie przez samorządy realizacji zadań publicznych organizacjom pozarządowym ( 84 wskazania) oraz konsultowanie z podmiotami trzeciego sektora projektów aktów prawa lokalnego, których proponowane rozwiązania mogą mieć wpływ na funkcjonowanie organizacji pozarządowych na określonym terenie lub w ramach określonego rodzaju prowadzonej działalności (72 wskazania). Natomiast do ostatniej grupy należy współpraca przejawiająca się w formie umów o wykonanie inicjatywy lokalnej (52 wskazania) i realizacji projektów na podstawie umowy partnerskiej (46 wskazań), będących klasycznym przejawem partnerstwa publiczno-społecznego. Zupełnie sporadycznie (w 9 przypadkach) zdarzało się, że organizacje uzyskały od samorządów wsparcie w postaci gwarancji i poręczeń pod udzielany im kredyt, czy pożyczkę. Wygląda na to, że 
samorządy wolą same wspomóc finansowo działalność organizacji, mając teoretycznie większą kontrolę nad wydatkowanymi środkami.

Koncentracja na wsparciu o charakterze finansowym, w ramach realizacji przez organizacje nałożonych na samorządy lokalne zadań publicznych, nie jest najlepszym rozwiązaniem. Oczywiście organizacje pozarządowe potrzebują pieniędzy, aby móc funkcjonować, bo przecież wszystkiego nie można załatwić wolontariatem, ale wydaje się, że częściej powinno dochodzić do realizacji wspólnych projektów partnerskich, czy inicjatyw lokalnych, gdzie podmioty należące do trzeciego sektora byłyby w większym stopniu równoprawnym partnerem dla samorządów, pomysłodawcą wspólnych działań, a nie byłyby tylko traktowane jak petent, wyciągający ręce po publiczne środki, czy podmiot wypełniający dość bezrefleksyjnie za te pieniądze zadania, spoczywające na samorządach.

W ramach poszczególnych obszarów działalności organizacji pozarządowych widać jednak pod tym kątem pewne zróżnicowanie. Jeśli chodzi o powierzanie realizacji zadań, to proporcjonalnie najczęściej korzystają z tej formy organizacje działające w obszarze ochrony i promocji zdrowia, a w następnej kolejności zajmujące się działalnością kulturalną i propagowaniem kultury. Z kolei najrzadziej ta forma jest wykorzystywana $\mathrm{w}$ ramach współpracy $\mathrm{z}$ organizacjami zajmującymi się działalnością informacyjną, a w następnej kolejności szkoleniowo-doradczą. Bardzo podobnie przedstawia się sytuacja, $w$ odniesieniu do wspierania realizacji przez organizacje pozarządowe zadań publicznych, nałożonych na samorządy oraz udzielania przez samorządy lokalne gwarancji i poręczeń dla badanych organizacji, z tą różnica, że to w przypadku działalności kulturalnej - najczęściej, a w przypadku działalności szkoleniowo-doradczej - najrzadziej dochodzi do wykorzystywania tych form współpracy międzysektorowej. Realizacja projektów partnerskich, to forma najczęściej wykorzystywana w działalności szkoleniowo-doradczej, a w następnej kolejności w przypadku podmiotów z obszaru działalności kulturalnej i propagowania kultury. Najsłabiej pod tym względem wypada współpraca z podmiotami zajmującymi się ochroną i promocją zdrowia. W przypadku umów o wykonanie inicjatywy lokalnej, miejsce podmiotów zajmujących się działalnością kulturalną zajęly te, które starają się przede wszystkim aktywizować i wspomagać rozwój lokalnych wspólnot, a organizacje działające w obszarze kultury uplasowały się natomiast na ostatnim miejscu. Również wzajemne informowanie o priorytetach, planowanych do realizacji projektach jest najmniej popularną formą współpracy z organizacjami z obszaru kultury. W tym przypadku proporcjonalnie najczęściej dochodzi do współpracy w obszarze informacji przyczyniającej się do podnoszenia poziomu innowacyjności (działalność informacyjna) oraz propagowania kultury fizycznej i zdrowego stylu życia. Do konsultacji zapisów w projektach lokalnych aktów normatywnych oraz tworzenia wspólnych zespołów doradczych i inicjatywnych najczęściej dochodzi z podmiotami, działającymi w obszarach: szkolenie i doradztwo oraz informacja, a najrzadziej w przypadku badanych podmiotów zajmujących się ochroną i promocją zdrowia oraz działalnością kulturalną i propagowaniem kultury. 
146 Udział podmiotów trzeciego sektora w rozwoju kapitału ludzkiego w regionie łódzkim

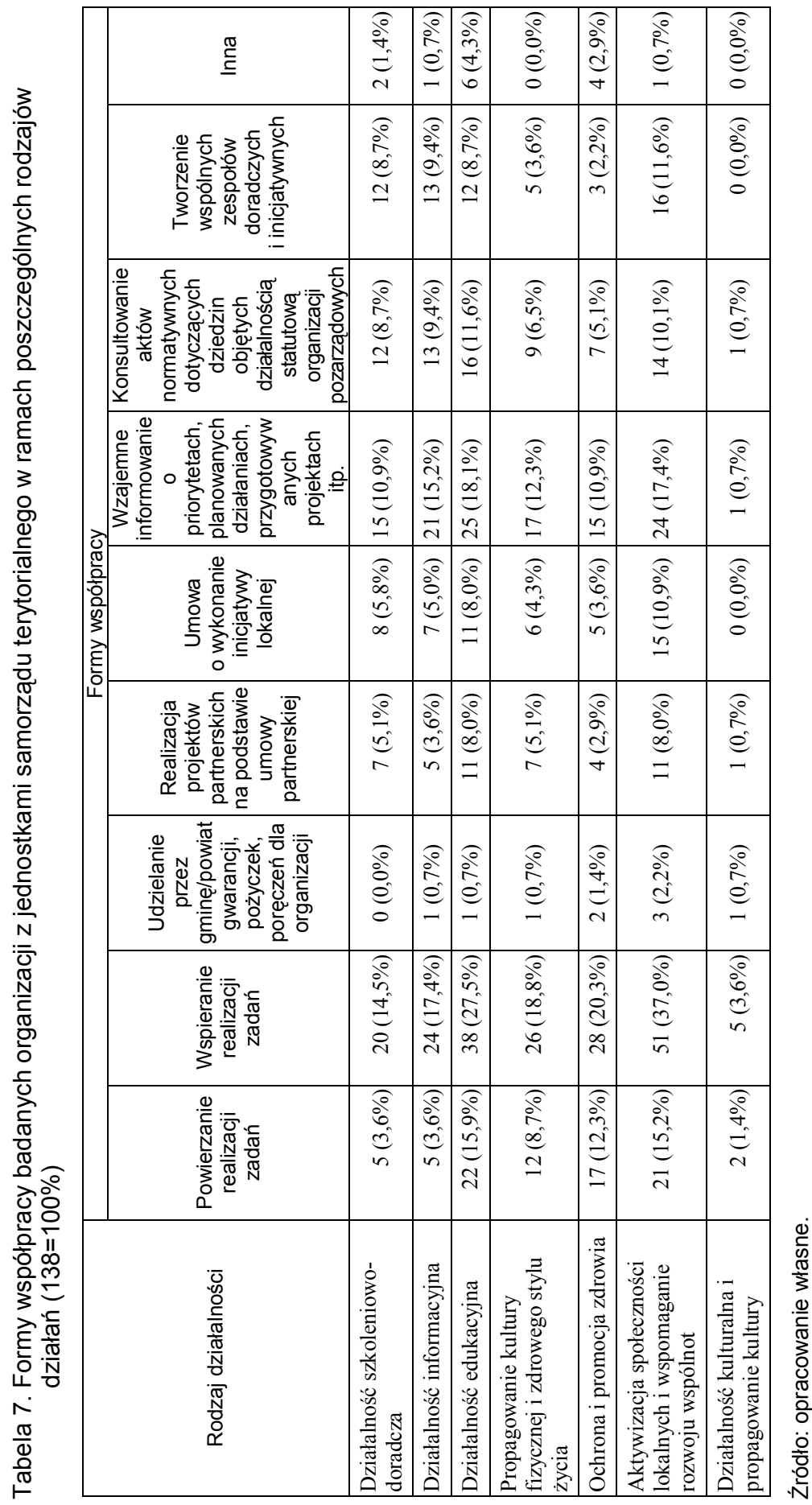


Jak głosi znane powiedzenie: jak nie wiadomo, o co chodzi, to chodzi o pieniądze. Niestety brakuje ich na podejmowanie współpracy władz samorządowych z organizacjami pozarządowymi, co zgłosiło, jako barierę współpracy, prawie $2 / 3$ organizacji pozarządowych.

Gorsze jest chyba jednak to, że w następnej kolejności badani wskazują na brak woli współpracy ze strony jst oraz traktowanie organizacji pozarządowych wyłącznie, czy przynajmniej głównie, jako petenta starającego się o pozyskanie środków publicznych, którymi dysponują samorządy lokalne (odpowiednio $31,0 \%$ i $29,0 \%$ wskazań). Porównując te wyniki z odpowiedziami udzielonymi przez badane i opisywane już wcześniej samorządy lokalne widać spore rozbieżności w postrzeganiu tych samych barier. Na brak środków, jako barierę współpracy i brak woli współpracy ze strony samorządów wskazało prawie połowę więcej jst (odpowiednio 87,8\% i 18,6\% odpowiadających jst). W przypadku traktowania organizacji pozarządowych jako petenta różnica ta jest jeszcze większa, gdyż nie $29 \%$, a jedynie $1,9 \%$ samorządów zaznaczyło taką odpowiedź w swoim kwestionariuszu. Z kolei znacznie mniej organizacji mówi o braku potrzeby współpracy z samorządami lokalnymi, niż ma to miejsce w przypadku oceny dokonanej przez udzielających odpowiedzi samorządowców (odpowiednio 4,8\% i 19,2\% odpowiedzi). Znając życie, prawda dotycząca skali opisanych powyżej barier leży gdzieś pośrodku. Bardzo zbliżony odsetek odpowiedzi pojawia się w przypadku wskazań na brak lub ograniczone zaufanie do organizacji ze strony samorządów (odpowiednio 18,6\% w badaniu skierowanym do jst i $19,3 \%$ w badaniu skierowanym do organizacji). W przypadku braku lub ograniczonego zaufania do jst ze strony organizacji różnica jest już jednak duża, bo na tę barierę wskazuje prawie dwa razy więcej organizacji, niż samorządów. Choć to już zostało wspomniane przy okazji analizy wyników badań samorządów, warto jeszcze raz podkreślić, iż jest to bardzo niepokojące zjawisko. Bez zaufania nie ma bowiem w ogóle mowy o współpracy, a nawet w przypadku ograniczonego zaufania jest ona bardzo utrudniona.

Prawie co piąta badana organizacja narzeka na brak odpowiedniej do jej potrzeb (a może właściwszym słowem byłoby - wymogów) oferty współpracy z samorządami. Jednocześnie prawie trzy razy mniej organizacji wspomina o niedostosowaniu swojej oferty do potrzeb mieszkańców, przedsiębiorców i innych podmiotów istniejących na terenie działania tych organizacji. Przy czym jedynie 4 spośród 17 organizacji, które mają zastrzeżenia do możliwości podejmowania współpracy oferowanych przez samorządy $(23,5 \%)$, jednocześnie samo widzi $\mathrm{u}$ siebie niedostosowanie lub jakieś niedociągnięcia $\mathrm{w}$ ofercie skierowanej do ich klientów. Wydaje się, że przynajmniej niektóre z badanych organizacji prezentują postawę zbyt roszczeniowa, zapominając o tym, że samo istnienie, albo dawne zasługi nie są powodem do podejmowania lub kontynuowania $\mathrm{z}$ taką organizacją współpracy ze strony samorządów. Na tę współpracę powinny liczyć jedy- 
nie te organizacje, których efekty działalności przynoszą rzeczywiste korzyści dla podejmujących z nimi współpracę i wspierających je samorządów lokalnych.

Tabela 8. Bariery współpracy badanych organizacji pozarządowych z jednostkami samorządu terytorialnego $(145=100 \%)$

\begin{tabular}{|l|r|r|}
\hline \multicolumn{1}{|c|}{ Rodzaj bariery } & Liczba & $\%$ \\
\hline $\begin{array}{l}\text { Brak/niewystarczająca ilość środków, które mogłyby zostać przeznaczone na } \\
\text { współpracę przez jst }\end{array}$ & 90 & 62,1 \\
\hline Brak zaufania do jst ze strony organizacji pozarządowych & 9 & 6,2 \\
\hline Ograniczone zaufanie do jst ze strony organizacji pozarządowych & 13 & 9,0 \\
\hline Brak zaufania jst wobec organizacji pozarządowych & 9 & 6,2 \\
\hline Ograniczone zaufanie jst wobec organizacji pozarządowych & 19 & 13,1 \\
\hline $\begin{array}{l}\text { Niedostosowanie oferty organizacji pozarządowych do potrzeb mieszkań- } \\
\text { ców, podmiotów gospodarczych i innych instytucji }\end{array}$ & 9 & 6,2 \\
\hline $\begin{array}{l}\text { Niedostosowanie oferty jst (warunków, form itp.) do potrzeb organizacji } \\
\text { pozarządowych }\end{array}$ & 26 & 17,9 \\
\hline Brak potrzeby współpracy ze strony organizacji pozarządowych & 7 & 4,8 \\
\hline Brak woli współpracy ze strony jst & 45 & 31,0 \\
\hline $\begin{array}{l}\text { Traktowanie organizacji pozarządowych, jako konkurenta dla podmiotów } \\
\text { należących do sektora samorządowego }\end{array}$ & 20 & 13,8 \\
\hline $\begin{array}{l}\text { Traktowanie organizacji pozarządowych wyłącznie/głównie, jako petenta w } \\
\text { sprawie pozyskania środków publicznych }\end{array}$ & 42 & 29,0 \\
\hline $\begin{array}{l}\text { Ograniczone możliwości podejmowania współpracy, wynikające m.in. z } \\
\text { braku równego dostępu organizacji pozarządowych do informacji }\end{array}$ & 7 & 4,8 \\
\hline Inne & 5 & 3,4 \\
\hline
\end{tabular}

Źródło: opracowanie własne.

Niestety prawie co trzeci przedstawiciel badanych organizacji, pytany o możliwości wprowadzenia w nich zmian, które pozwoliłyby im na zwiększenie wpływu na podnoszenie poziomu kapitału ludzkiego w ramach terytorium, na którym działają - odpowiedział, że niemożliwe jest dokonanie jakichkolwiek zmian przy obecnych środkach finansowych. Wydaje się, że przynajmniej niektóre z wymienionych przez pozostałe osoby zmian (chociażby lepsza organizacja działalności i wykorzystanie dostępnych środków finansowych, czy nawet w pewnym stopniu podnoszenie poziomu własnych kompetencji) nie wymagają poniesienia dodatkowych nakładów finansowych, a przede wszystkim chęci ich wprowadzenia.

Spośród propozycji zmian na czoło wysuwa się zdecydowanie intensyfikacja, zwiększenie aktywności podejmowanych działań (więcej niż co czwarty udzielający odpowiedzi). W następnej kolejności wskazywane jest rozszerzenie zakresu działalności oraz większa promocja samych organizacji i tego, czym się zajmują. 
Do kolejnej grupy, pod względem ilości wskazań, należy zaliczyć wspomnianą już lepszą organizację działalności i wykorzystanie dostępnych środków finansowych oraz podnoszenie poziomu własnych kompetencji, a także sięganie po dostępne środki pomocowe.

Szkoda, że tak rzadko badani myślą o zwiększaniu swoich możliwości poprzez tworzenie i uczestnictwo w sieciach współpracy, w których istnienie i działalność zaangażowane byłyby zarówno inne podmioty należące do trzeciego sektora, samorządy lokalne, jak i inne podmioty (komercyjne) chcące przyczynić się do podnoszenia poziomu kapitału ludzkiego określonego terytorium.

Wśród innych odpowiedzi pojawiało się m.in. uruchomienie własnej strony internetowej, czy większe zaangażowanie osób uczestniczących w działalności organizacji. Osoby reprezentujące w badaniu pozostałe 28 ze 155 organizacji pozarządowych uciekały natomiast najczęściej od odpowiedzi mówiąc, że nie potrafią odpowiedzieć na to pytanie, choć zdarzały się również odpowiedzi typu - nie wiem, wszystko jest OK.

Tabela 9. Propozycje zmian w badanych organizacjach pozarządowych mających umożliwić im zwiększenie wpływu na podnoszenie poziomu kapitału ludzkiego $(127=100 \%)$

\begin{tabular}{|l|c|c|}
\hline \multicolumn{1}{|c|}{ Rodzaj zmian } & Liczba & $\%$ \\
\hline Zwiększenie aktywności - intensyfikacja podejmowanych działań & 27 & 21,3 \\
\hline Rozszerzenie zakresu działalności & 20 & 15,7 \\
\hline $\begin{array}{l}\text { Większa promocja umożliwiająca zwiększenie zaufania i wzrost zainte- } \\
\text { resowania mieszkańców działalnością organizacji }\end{array}$ & 18 & 14,2 \\
\hline $\begin{array}{l}\text { Lepsza organizacja działalności i wykorzystanie dostępnych środków } \\
\text { finansowych }\end{array}$ & 13 & 10,2 \\
\hline Podnoszenie poziomu własnych kompetencji & 13 & 10,2 \\
\hline Aplikowanie o środki pomocowe (zarówno krajowe, jak i zagraniczne) & 12 & 9,4 \\
\hline Stworzenie/rozszerzenie sieci współpracy z innym organizacjami & 5 & 3,9 \\
\hline Wzmocnienie/rozszerzenie współpracy z jst & 5 & 3,9 \\
\hline Posiadanie lepszego wyposażenia & 3 & 2,4 \\
\hline Inne & 5 & 3,9 \\
\hline $\begin{array}{l}\text { Niewystarczająca ilość środków finansowych, żeby móc zrobić jeszcze } \\
\text { coś więcej }\end{array}$ & 39 & 30,7 \\
\hline
\end{tabular}

Źródło: opracowanie własne.

Ze strony samorządów, badane organizacje oczekują przede wszystkim zwiększenia kompetencji i zaangażowania osób odpowiedzialnych w urzędach za współpracę $\mathrm{z}$ organizacjami pozarządowymi (co czwarty badany podmiot) oraz zmiany podejścia do współpracy z organizacjami: chciałyby traktowania 
ich przez samorządy, jako równoprawnych partnerów, a nie petentów (wskazanie ze strony $23,3 \%$ badanych organizacji) i stworzenia, a później przestrzegania czytelnych procedur współpracy (22,6\% wskazań). Wydaje się, że tego typu propozycje są jak najbardziej uzasadnione, a ich realizacja nie wiąże się z ponoszeniem ze strony samorządów jakichś dużych dodatkowych środków finansowych.

Większa pomoc o charakterze pozafinansowym oraz promocja samej idei trzeciego sektora i efektów działalności organizacji pozarządowych, to kolejna pod względem popularności grupa propozycji zmian, które powinny zdaniem przedstawicieli organizacji pozarządowych przyczynić się do zwiększenia możliwości wpływania przez organizacje na poziom kapitału ludzkiego w ramach określonej jednostki samorządu terytorialnego.

Tabela 10. Propozycje zmian po stronie jst mające umożliwić badanym organizacjom zwiększenie wpływu na podnoszenie poziomu kapitału ludzkiego $(127=100 \%)$

\begin{tabular}{|l|c|c|}
\hline \multicolumn{1}{|c|}{ Rodzaj zmian } & Liczba & $\%$ \\
\hline $\begin{array}{l}\text { Zwiększenie kompetencji i zaangażowania osób odpowiedzialnych w jst } \\
\text { za współpracę z organizacjami pozarządowymi }\end{array}$ & 34 & 25,6 \\
\hline $\begin{array}{l}\text { Współpraca z organizacjami pozarządowymi na zasadach partnerstwa, a } \\
\text { nie traktowanie ich jak petenta }\end{array}$ & 31 & 23,3 \\
\hline $\begin{array}{l}\text { Stworzenie/uproszczenie i przestrzeganie czytelnych procedur współpra- } \\
\text { cy z organizacjami pozarządowymi }\end{array}$ & 30 & 22,6 \\
\hline Większa pomoc pozafinansowa dla organizacji pozarządowych & 25 & 18,8 \\
\hline Promowanie działalności organizacji pozarządowych & 22 & 16,5 \\
\hline $\begin{array}{l}\text { Zaprzestanie przeszkadzania/utrudniania działalności organizacjom } \\
\text { pozarządowym }\end{array}$ & 12 & 9,0 \\
\hline $\begin{array}{l}\text { Dostosowanie programów współpracy do potrzeb i możliwości organiza- } \\
\text { cji pozarządowych }\end{array}$ & 12 & 9,0 \\
\hline Większa pomoc finansowa dla organizacji pozarządowych & 14 & 8,8 \\
\hline $\begin{array}{l}\text { Zwiększenie poziomu przekazywania realizacji zadań publicznych do } \\
\text { organizacji pozarządowych }\end{array}$ & 11 & 8,3 \\
\hline Inne* & 11 & 8,3 \\
\hline
\end{tabular}

* w tej grupie dominowały 2 typy odpowiedzi: współpraca układa się bardzo dobrze, nie ma czego zmieniać oraz chcielibyśmy, żeby zaczęli w nas wierzyć, w to, co robimy.

Źródło: opracowanie własne.

O tym, że finanse nie są aż tak ważne dla organizacji pozarządowych może świadczyć również fakt, że zwiększenie pomocy finansowej dla organizacji jest jedną z rzadziej wymienianych propozycji zmian $(8,8 \%$ wskazań na tę odpowiedź). Chociaż można się zastanawiać, na ile propozycja zwiększenia poziomu 
przekazywania realizacji zadań publicznych $\mathrm{w}$ ręce organizacji pozarządowych (8,3\% wskazań), wynika $\mathrm{z}$ chęci przyczynienia się do lepszego zaspokajania potrzeb członków lokalnej społeczności oraz podmiotów gospodarczych i innych organizacji działających na danym terenie, a na ile powodowane jest to chęcią poprawy, czy ustabilizowania swojej sytuacji poprzez korzystanie przez organizacje ze środków przekazywanych przez samorządy na ich realizację. Łącznie daje to już 19,1\%.

\section{Podsumowanie}

Wyniki zrealizowanych badań pozwalają na sformułowanie następujących wniosków:

1) samorządy lokalne bardzo często angażują w proces tworzenia programów współpracy z organizacjami pozarządowymi jej reprezentantów, ale dopiero na etapie opiniowania gotowych projektów. Zbyt rzadko korzystają natomiast przy opracowywaniu programów współpracy z ich pomocy i propozycji już na etapie zbierania informacji potrzebnych do opracowania programu. Co ciekawe, badane organizacje pozarządowe twierdzą jednak, że częściej niż do opiniowania gotowych projektów, dochodzi do konsultacji z nimi przy ustalaniu potrzeb mieszkańców i samych organizacji. Trzeba jednak pamiętać, że przebadane organizacje nie stanowią całości populacji i w związku z tym ich opinie nie muszą podważać wiarygodności odpowiedzi udzielonych przez przedstawicieli samorządów;

2) wszystkie z badanych samorządów zadeklarowały współpracę z przynajmniej jedną $z$ organizacji pozarządowych, której działalność może wpływać na rozwój kapitału ludzkiego, przy czym największą popularnością cieszą się organizacje zajmujące się propagowaniem kultury fizycznej i zdrowego stylu życia. Zbyt rzadko współpracują natomiast $\mathrm{z}$ organizacjami zajmującymi się działalnością szkoleniowo-doradczą i informacyjną, a nawet edukacyjną, a są to przecież obszary bardzo ważne z punktu widzenia możliwości podnoszenia jakości kapitału ludzkiego na poziomie lokalnym (a w konsekwencji i regionalnym). Przynajmniej częściowym usprawiedliwieniem może być przy tym proporcjonalnie mała, na tle ogólnej liczby, ilość organizacji działających $w$ tych obszarach oraz relatywnie niska ocena efektów ich działalności;

3) zbyt często współpraca samorządów lokalnych z organizacjami pozarządowymi, których działalność może przyczyniać się do rozwoju kapitału ludzkiego ogranicza się jedynie do wymiany informacji o podejmowanych działaniach i przygotowywanych projektach rozwiązań, mogących mieć wpływ na działalność organizacji oraz wsparcia finansowego w realizacji przez nie 
zadań publicznych. Zbyt rzadko z kolei dochodzi do współpracy w ramach relacji partnerskich - tworzenia zespołów problemowych i realizacji wspólnych projektów, podpisywania umów partnerstwa;

4) samorządy lokalne widzą jednak korzyści ze współpracy z organizacjami pozarządowymi - zarówno dla siebie, swoich mieszkańców, ale i samych organizacji. Należą do nich przede wszystkim: aktywizacja mieszkańców, zwiększenie kompetencji, zakresu oferty i redukcja kosztów realizacji nałożonych ustawowo zadań publicznych po stronie samorządów i członków lokalnej społeczności oraz wsparcie ze strony samorządów (głównie finansowe, ale i pozafinansowe) dla organizacji pozarządowych;

5) nadal główną barierą dla podejmowania współpracy są ograniczone środki finansowe po stronie samorządów, a w następnej kolejności brak woli współpracy z obydwu stron, przy czym czynnikiem mającym silny wpływ na taki stan rzeczy może być utrzymująca się jeszcze wzajemna nieufność i świadomość korzyści wynikających z podjęcia współpracy;

6) jednocześnie organizacje pozarządowe wskazują na możliwości zwiększania przez nie wpływu na podnoszenie poziomu kapitału ludzkiego przede wszystkim poprzez zwiększenie własnej aktywności, podnoszenie kompetencji i zmianę postaw osób odpowiedzialnych za współpracę z nimi ze strony samorządów.

W kontekście przedstawionej analizy zebranego materiału uzasadnionym wydaje się stwierdzenie, że samorządy lokalne nie wykorzystują w pełni (chociażby ze względu na wymieniany już kilkukrotnie brak woli współpracy i zaufania do organizacji pozarządowych oraz zbyt rzadkie traktowanie ich jako równoprawnych partnerów, a nie petentów w kolejce po publiczną kasę) potencjału, jakim dysponują organizacje pozarządowe (potwierdzenie słuszności założeń pierwszej tezy badawczej). $Z$ drugiej strony, głównie z powodu braku, czy ograniczonego zaufania do samorządów, ale i słabości kompetencyjnych i organizacyjnych podmiotów należących do trzeciego sektora, nie zawsze są one w stanie skorzystać z możliwości podjęcia współpracy oferowanych przez samorządy lokalne (potwierdzenie założeń tezy drugiej). Częściowe potwierdzenie w uzyskanych wynikach badań znalazła również teza trzecia, mówiąca o ograniczaniu się przez samorządy głównie do współpracy w formie wsparcia finansowego. Chociaż w tym przypadku należałoby dodać jeszcze konsultacje i wzajemną wymianę informacji, jako prawie równie popularne, lecz już w mniej bezpośredni sposób przyczyniające się do podnoszenia jakości kapitału ludzkiego, formy współpracy międzysektorowej.

Wyłaniający się z prezentowanego materiału obraz jest z pewnością daleki od ideału i żeby go poprawić, niezbędne wydają się w pierwszej kolejności zmiany $\mathrm{w}$ mentalności, otwartości na kwestie współpracy międzysektorowej osób reprezentujących zarówno samorządy lokalne, jak i organizacje pozarzą- 
dowe. Ważne jest uświadomienie im, m. in. przez promocję dobrych praktyk, korzyści wynikających z nawiązywania i rozszerzania takiej współpracy. Te zmiany wydają się być najistotniejsze, ze względu na większą łatwość ich zrealizowania - bo na istotnie większe środki, które będą przeznaczane ze strony samorządów na współprace $\mathrm{z}$ organizacjami w najbliższym czasie raczej nie ma co liczyć. Poza tym, sami przedstawiciele badanych organizacji w propozycjach zmian, do których powinno dojść po stronie samorządów, częściej wskazywali na potrzebę zwiększenia pomocy o charakterze pozafinansowym, niż na zwiększanie dopływu pomocy w formie finansowej. Jeśli chodzi natomiast o pieniądze, to ważne, żeby te, którymi dysponują samorządy, były rozdysponowywane w sposób możliwie najefektywniejszy i nie budzący wątpliwości, co do słuszności i rzetelności przekazywania do poszczególnych organizacji pozarządowych działających na ich terenie. To powinno sprzyjać nawiązywaniu współpracy międzysektorowej, której motywem nie będzie już wyłącznie obowiązek (po stronie samorządów lokalnych), w postaci konieczności wypełnienia warunków przewidzianych w obowiązujących przepisach prawnych, czy chęć „zapolowania" na publiczne pieniądze (po stronie organizacji pozarządowych), a świadomość obopólnych korzyści wynikających z tej współpracy i wspólnie wypracowana wizja skuteczniejszego wpływania na podnoszenie poziomu kapitału ludzkiego, a w konsekwencji rozwój terytorium, za którego teraźniejszość, ale i przyszłość odpowiadają.

\section{Bibliografia}

Bontis N., National intellectual capital index; the benchmarking of Arab Countries, Journal of Intellectual Capital, 2002.

Florczak W., Kapitat ludzki a rozwój gospodarcz, [w:] Gospodarka oparta na wiedzy, Welfe W. (red.), Polskie Wydawnictwo Ekonomiczne, Warszawa 2007.

Gałązka A. (red.), Elementarz III sektora, Stowarzyszenie Klon/Jawor, Warszawa 2005.

Gumkowska M., Herbst J., Radecki P., Podstawowe fakty o organizacjach pozarzadowych. Raport z badania 2008, Stowarzyszenie Klon/Jawor, Warszawa 2009.

John P., Governance In Western Europe, SAGE Publications Ltd., London-Thousand Oaks-New Delhi 2004.

Jewtuchowicz A., Terytorium i współczesne dylematy jego rozwoju, Wydawnictwo Uniwersytetu Łódzkiego, Łódź 2005.

Kietlińska K., Rola trzeciego sektora $w$ społeczeństwie obywatelskim, Wydawnictwo Difin, Warszawa 2010.

Lasocik Z., Kilka uwag o roli organizacji pozarzqdowych w państwie demokratycznym, Fundusz Współpracy, Warszawa 1994.

Leś E., Działalność dobroczynna w Europie i Ameryce. Tradycje $i$ współczesność, BORDO, Warszawa 1999. 
154 Udział podmiotów trzeciego sektora w rozwoju kapitału ludzkiego w regionie łódzkim

Leś E., Od filantropii do pomocniczości. Studium porównawcze rozwoju i działalności organizacji spolecznych, Dom Wydawniczy ELIPSA, Warszawa 2000.

Przewłocka J., Polskie organizacje pozarzqdowe 2012, Stowarzyszenie Klon/Jawor, Warszawa 2013.

Przewłocka J., Adamiak P., Herbst J., Podstawowe fakty o organizacjach pozarzadowych - raport z badania 2012, Stowarzyszenie Klon/Jawor, Warszawa 2013.

Wygnański J., Terminologia [w:] Elementarz III sektora, Gałązka A. (red.), Stowarzyszenie Klon/Jawor, Warszawa 2005.

Zalewski A., Reformy sektora publicznego $w$ duchu nowego zarzadzania publicznego [w:] Nowe zarzadzanie publiczne w polskim samorzadzie terytorialnym, Zalewski A. (red), SGH, Warszawa 2007.

Załuska M., Prawne i organizacyjne ramy działania organizacji pozarzadowych [w:] Organizacje pozarzqdowe $w$ społeczeństwie obywatelskim, Załuska M., Boczoń J. (red.), Wydawnictwo Śląsk, Katowice 1998. 